\title{
Naar een toekomstbestendig cohortonderzoek
}

\author{
Citation for published version (APA):
}

van der Velden, R. K. W., \& van der Maas, H. (2015). Naar een toekomstbestendig cohortonderzoek. ROA. ROA Reports No. 001 https://doi.org/10.26481/umarep.2015001

Document status and date:

Published: 01/01/2015

DOI:

10.26481/umarep.2015001

\section{Please check the document version of this publication:}

- A submitted manuscript is the version of the article upon submission and before peer-review. There can be important differences between the submitted version and the official published version of record.

People interested in the research are advised to contact the author for the final version of the publication, or visit the DOI to the publisher's website.

- The final author version and the galley proof are versions of the publication after peer review.

- The final published version features the final layout of the paper including the volume, issue and page numbers.

Link to publication

\footnotetext{
General rights rights.

- You may freely distribute the URL identifying the publication in the public portal. please follow below link for the End User Agreement:

www.umlib.nl/taverne-license

Take down policy

If you believe that this document breaches copyright please contact us at:

repository@maastrichtuniversity.nl

providing details and we will investigate your claim.
}

Copyright and moral rights for the publications made accessible in the public portal are retained by the authors and/or other copyright owners and it is a condition of accessing publications that users recognise and abide by the legal requirements associated with these

- Users may download and print one copy of any publication from the public portal for the purpose of private study or research.

- You may not further distribute the material or use it for any profit-making activity or commercial gain

If the publication is distributed under the terms of Article $25 \mathrm{fa}$ of the Dutch Copyright Act, indicated by the "Taverne" license above, 


\section{NAAR EEN TOEKOMSTBESTENDIG COHORTONDERZOEK}

ROA-R-2015/1

Rolf van der Velden (UM/ROA)

Han van der Maas (UvA) 


\section{Colofon}

(C) Researchcentrum voor Onderwijs en Arbeidsmarkt (ROA). Niets uit deze uitgave mag op enige manier worden verveelvoudigd zonder voorafgaande schriftelijke toestemming van de directeur van het ROA.

\section{Researchcentrum voor Onderwijs en Arbeidsmarkt}

School of Business and Economics

Maastricht University

\section{Vormgeving}

ROA secretariaat, Maastricht

\section{Verkoop}

Researchcentrum voor Onderwijs en Arbeidsmarkt email: secretary-roa-sbe@maastrichtuniversity.nl

website: www.roa.nl

ISBN: 978-90-5321-537-1 


\section{INHOUD}

01 Inleiding

O2 Evaluatie van $\mathrm{COOL} \quad 5$

$\begin{array}{ll}03 \text { Toekomstig design } & 19\end{array}$

04 Ontsluiting en onderhoud bestaande gegevens 33

05 Samenvatting en conclusie $\quad 35$

APPENDIX 1 Lijst met gesprekken $\quad 39$

APPENDIX 2 Respons dataverzameling $\quad 41$

APPENDIX 3 Overzicht COOL-publicaties (o.b.v. opgave aan PROO) 43

APPENDIX 4 Mailverkeer met DANS om data beschikbaar te krijgen 53

APPENDIX 5 Beleid CBS inzake toegang microdata $\quad 55$ 



\section{1 \\ INLEIDING}

De Programmaraad voor fundamenteel onderwijsonderzoek (PROO) van het Nationaal Regieorgaan Onderwijsonderzoek (NRO) heeft in het najaar van 2013 een commissie ingesteld met als opdracht de PROO te adviseren over de toekomst van het door de PROO gefinancierde cohortonderzoek. Aanleiding is het feit dat de subsidieperiode voor het lopende cohortonderzoek $\mathrm{COOL}^{5-18}$ (vanaf nu aangeduid als COOL) in 2016 afloopt. De vraag aan de commissie was of en zo ja op welke wijze hieraan in 2017 een vervolg dient te worden gegeven.

De commissie onder voorzitterschap van Prof. Lex Borghans heeft op 22 oktober 2014 haar advies uitgebracht. Hierin concludeert de commissie dat COOL om allerlei redenen niet heeft opgeleverd wat indertijd verwacht werd. Er worden grote problemen geconstateerd zoals:

- De geringe responsbereidheid bij scholen.

- Problemen in het design: vanwege de uitwaaiering van leerlingen bij de overgangen tussen PO en VO, resp. VO en vervolgonderwijs is het lastig is om leerlingen goed te volgen. Hierdoor is de koppeling van de data tussen PO en VO zo goed als mislukt. Ook de dataverzameling in het MBO is zo goed als mislukt.

- Beperkte bruikbaarheid van onderzoeksresultaten voor de evaluatie van nationaal onderwijsbeleid.

- Onvoldoende toegankelijkheid van de data voor onderzoekers buiten het consortium en onvoldoende mogelijkheden voor onderzoekers buiten het consortium om hun eigen onderzoeksvragen in te brengen in het $\mathrm{COOL}$ onderzoek.

- Vertraging in de oplevering van de data.

- Onvoldoende wetenschappelijke resultaten.

De geconstateerde problemen vormen op zichzelf al een goede aanleiding om bij het aflopen van de subsidieperiode een bezinning in te lassen op welke wijze het cohortonderzoek moet worden voortgezet. Daar komen twee andere ontwikkelingen bij:

- Ten eerste zijn er tegenwoordig meer mogelijkheden om data op een andere wijze te verzamelen dan in de tijd van het ontwerp van COOL. De verruimde mogelijkheden van de registerdata, de ontwikkeling van leerlingvolgsystemen en de verplichte rapportages van scholen aan de inspectie voorzien mogelijk al in een belangrijk deel van de gewenste data. 
- Ten tweede is er een aantal grootschalige dataverzamelingen die reeds in internationaal verband worden uitgevoerd die op dit moment volledig los staan van COOL: bijvoorbeeld PISA, TIMSS, PIRLS en ICCS. Het is belangrijk om na te gaan of en op welke wijze deze geïntegreerd kunnen worden in het cohortdesign. Een concrete aanleiding hiervoor is ook het voorgenomen OECD onderzoek 'Longitudinal Study of Skills Development in Cities' (LSSDC). Dit betreft een initiatief om de ontwikkeling in sociaal-emotionele vaardigheden van kinderen te volgen in twee cohorten: 12-jarigen (hoofdstudie te starten in 2019-2020) en 6-jarigen (hoofdstudie te starten enkele jaren later). Beide panels zouden een looptijd hebben van een jaar of zes zodat de gehele schoolloopbaan bestreken wordt.

Naar aanleiding van het advies van de commissie hebben OCW en NRO een gezamenlijke vervolgopdracht geformuleerd. Hierbij gaat het om het formuleren van een advies over de toekomst van het cohortonderzoek, waarbij de meerwaarde van cohortonderzoek geëxpliciteerd wordt en een beredeneerde keuze wordt gemaakt voor een bepaalde opzet. Daarbij dient:

- nagegaan te worden welke witte vlekken er zijn bij de bestaande dataverzamelingen (waaronder registerdata), en waar ondoelmatige overlap bestaat;

- de mogelijkheid onderzocht te worden of een nieuw cohort kan aansluiten bij het eerdere genoemde OECD initiatief;

- gekeken te worden naar mogelijke alternatieven, met name het volgen van individuele leerlingen;

- gekeken te worden of door gebruik van registerdata de belasting van scholen kan afnemen, waarbij ook aandacht moet zijn voor informatie over de omgeving (ouders, docenten);

- gekeken te worden naar vraagstukken rond het gebruik van data, met name privacyaspecten, eigendom, en toegang tot de data;

- een representatieve set vragen te formuleren die illustreren welke vragen met een dergelijke dataset beantwoord kunnen worden.

Om een goed advies te kunnen uitbrengen over de toekomst van het cohort onderzoek hebben we gemeend dat het ook belangrijk is om een goed inzicht te krijgen in het huidige COOL onderzoek. In de evaluatie studie hebben we ons met name geconcentreerd op de hoofdstudie COOL en zijn de belendende studies COOL-speciaal en Pre-COOL slechts zijdelings aan bod geweest. COOL-speciaal en COOL-PO lijken veel op elkaar. Ook in COOL-speciaal worden gegevens ontleend aan leerlingvolgsystemen (LVS), maar eindtoetsen zijn in het speciaal PO vooralsnog niet aanwezig. De indruk bestaat dat COOL-speciaal wel in een behoefte voorziet, zoals aangegeven door vertegenwoordigers van OCW. Met name de ontwikkeling van het zogeheten zorgprofiel is van belang omdat er geen landelijke gegevens bestaan over type zorgleerlingen, noch in het speciaal noch in het reguliere PO.

Pre-COOL heeft een hele andere opzet dan de overige onderzoeken. In Pre-COOL worden peuters gevolgd in hun ontwikkeling tot aan het einde van het PO. Het onder- 
zoek is gestart in 2010 op initiatief van OCW. Er vinden jaarlijkse metingen plaats van de ontwikkeling van jonge kinderen, startend op 2-jarige leeftijd tot en met 5 jaar. Daarna worden deze kinderen nog gevolgd tot einde basisonderwijs. Er is een apart budget voor beschikbaar gesteld van ongeveer 6 miljoen euro (ter vergelijking: het hele budget voor COOL bedraagt zo'n 10 miljoen euro). De werving vindt plaats via instellingen voor voor- en vroegschoolse educatie (VVE) met een aanvullende random steekproef van gezinnen (het gezinscohort). Hierin zitten kinderen met en zonder deelname aan een voorschoolse voorziening. In totaal bestaat de steekproef uit ongeveer 3.000 peuters, waarvan een kerncohort van 750 zo integraal in de opeenvolgende metingen is gevolgd. ${ }^{1}$ Het is een meer klassieke cohort opzet met veel eigen instrumenten, zoals ontwikkeling van aandacht, taalperceptie en taalgeheugen, omdat voor de doelgroep (2-jarigen) weinig instrumenten beschikbaar zijn. Daarnaast zijn ook bestaande instrumenten gebruikt. De totale test tijd bedraagt zo'n 45 minuten. Daarnaast zijn vragenlijsten ontworpen om het aanbod en kwaliteit van voorzieningen (bv. VVE) in kaart te brengen en zijn er lijsten voor de ouders. Er worden geen data gebruikt van de GGD.

Ook Pre-COOL is niet geheel probleemloos verlopen. Zo bedraagt de respons onder ouders slechts $50 \%$. Voor een deel komt dit omdat primair uitgegaan is van een schriftelijke benadering, maar ook de lengte van de vragenlijst kan een rol gespeeld hebben. Ook heeft het proces van data-cleaning lang geduurd omdat het proces van kalibreren en in elkaar schuiven van de schalen die in opeenvolgende metingen werden gebruikt gecompliceerd was. De dataverzameling is eveneens gecompliceerd en belastend voor zowel deelnemers als onderzoekers. Door de opzet met jaarlijkse metingen en benodigde rappels is er sprake van een continue dataverzameling zonder pauzes. Sommige onderzoekers geven ook aan dat ze liever op eerdere leeftijd zouden starten. De mogelijkheid om Pre-Cool door te laten lopen in COOL-PO bleek slechts gedeeltelijk mogelijk, vanwege de uitwaaiering over de verschillende basisscholen (dit is dus hetzelfde probleem als bij de aansluiting tussen COOL-PO en COOL-VO). Ook doet zich bij Pre-COOL de spanning voor tussen het belang dat sommige onderzoekers hebben bij het gebruik van data voor wetenschappelijk onderzoek (proefschriften) en het belang om deze data snel voor de academische wereld beschikbaar te stellen. Hoewel de data in principe na 2 jaar bij DANS liggen, worden aanvragen wel gecheckt door consortiumonderzoekers of dit niet interfereert met lopend onderzoek van de onderzoekers zelf (zie appendix 4). Dit bevordert niet een optimaal gebruik van de data door derden.

Niettemin is de opzet van Pre-COOL wel interessant. Onderzoek van onder andere Cunha en Heckman ${ }^{2}$ wijst uit dat de ontwikkeling in de voorschoolse leeftijd bepalend is voor de opbouw van skills tijdens de latere levensloop. Ook het effect van interventies lijkt het grootst wanneer deze op zeer jeugdige leeftijd worden gedaan. In die zin is het zinvol om te onderzoeken of een vergelijkbare opzet als Pre-COOL niet de basis zou kunnen worden van een nieuw te starten cohort onderzoek. We komen hier later op terug.

$1 \quad$ De overige leerlingen worden wel gevolgd, maar niet met alle instrumenten.

2 Cunha en Heckman (2007), The technology of skill formation, American Economic Review, 97 (2),31-47. 
Het advies is als volgt opgebouwd. In hoofdstuk 2 evalueren we de opzet en uitvoering van $\mathrm{COOL}$ aan de hand van een aantal verschillende aspecten: organisatie, onderzoeksdesign, instrumenten, dataverzameling, privacy, rapportages, relevantie voor beleid en beschikbaarheid van de data. Onze analyse is gebaseerd op de gesprekken die we hebben gevoerd met een groot aantal betrokkenen (zie appendix 1 voor een overzicht) en bestudering van een reeks documenten die in het kader van COOL zijn geproduceerd. De conclusies die we hieruit trekken zijn onze eigen conclusies, tenzij duidelijk anders aangegeven. Voor een belangrijk deel bevestigen deze de eerdere conclusies van de adviescommissie, maar er zijn ook belangrijke nuanceringen of andere interpretaties van dezelfde bevindingen. Ook dat zullen we in de tekst - waar relevant - aangeven. In hoofdstuk 3 schetsen we enkele uitgangspunten voor het toekomstig longitudinaal onderwijsonderzoek. We gaan in op de mogelijke vragen waar dergelijk onderzoek antwoord op moet geven, de mogelijke aansluiting bij internationaal onderzoek, het onderzoeksdesign, de organisatie, de instrumenten, de dataverzameling, en de ontsluiting van de data. Ten slotte wijden we een apart hoofdstuk aan de ontsluiting en onderhoud van de bestaande cohortgegevens. Hoewel dit geen expliciet onderdeel was van de opdracht, menen we dat er een taak ligt bij NRO om deze ontsluiting en bijbehorend onderhoud zeker te stellen. We eindigen met een samenvatting en conclusie. 


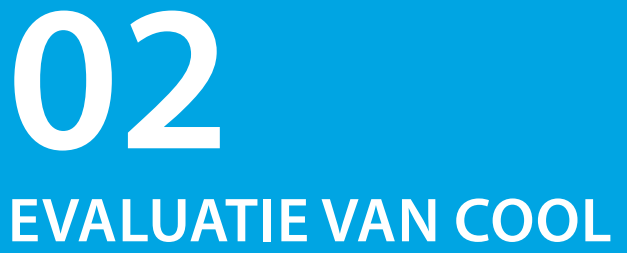

Organisatie

Oorspronkelijk waren er voor het COOL onderzoek drie offertes ingediend voor de uitvoering van het gehele COOL-traject. Een daarvan viel na beoordeling af en twee bleven over: één vanuit de combinatie ITS/KI en één vanuit de combinatie GION/ CITO. De opdracht werd aanvankelijk gegund aan ITS/KI, maar GION/CITO hebben hier bezwaar tegen aangetekend, vanwege vermeende onzorgvuldigheden in de toekenningsprocedure. Hierna is door PROO besloten om beide consortia te vragen een gezamenlijke offerte te maken en de partners een onderlinge taakafbakening te laten maken. Maar omdat beide voorstellen wel redelijk verschillend waren (bv. in steekproefdesign) was dat volgens de onderzoekers geen gemakkelijke opgave. Ook werd niet voor een heldere hiërarchische structuur gekozen waarbij één organisatie eindverantwoordelijk was. Dit heeft een schaduw gelegd over het gehele project.

Het meest opvallende daaraan is volgens ons het volledig ontbreken van enige vorm van regie of coördinatie. Hoewel wellicht vanuit PROO gezien sprake was van één consortium met 1 hoofdaanvrager, is dit de facto door de onderzoekers nooit zo ervaren. Illustratief hiervoor was dat al in de aanvraag gesproken wordt over twee consortia die het onderzoek uitvoeren en die elk verantwoordelijk zijn voor hun eigen deel. Door de gekozen structuur was geen van de consortiumpartners eindverantwoordelijk voor het geheel. Dat betekent dat afstemming hoofdzakelijk binnen de twee deelprojecten plaats vond. Veelzeggend is dat - met uitzondering van het overleg in de beginfase - in de hele periode van 10 jaar het consortium maar 2 keer bij elkaar is geweest voor inhoudelijk overleg. Wel zijn er gezamenlijke bijeenkomsten georganiseerd op de ORD en de AERA en is er een gezamenlijk website gemaakt. Naar onze indruk bestond er in het consortium geen gevoel van eenheid. Illustratief daarvoor is dat ten aanzien van de oplevering van data aan DANS geen onderlinge afspraken zijn gemaakt over wat precies opgeleverd gaat worden en in welk format. Maar - net zo opvallend - deze format-afspraken zijn ook niet door PROO of DANS verlangd.

Dat kan deels de onderzoekers zelf verweten worden (ze hebben bijvoorbeeld nagelaten om dit aan PROO te melden), maar ook PROO heeft nagelaten om dit te signaleren en één instituut de leiding te geven over het geheel. Op de wijze waarop het nu func- 
tioneerde is de facto sprake van een voortzetting van het oude model van afzonderlijk cohorten in het $\mathrm{PO}$ en $\mathrm{VO}$, met minimale afstemming tussen beide (met uitzondering van de afstemming in de designfase).

Ook de afspraken tussen partners, PROO en CBS verliepen gebrekkig. Het heeft lang geduurd voordat duidelijk werd wie wat moest doen en hoe het CBS in dit geheel betrokken moest worden. De gebrekkige samenwerking kwam deels door cultuurverschillen maar had wellicht door een strakke coördinatie vanuit de PROO voorkomen kunnen worden.

Ten slotte valt op het ontbreken van een goede overlegstructuur met beleidsmakers. Hoewel OCW wel bij de start van COOL betrokken is geweest, was er geen systematisch overleg tussen bv. de onderzoekscoördinatoren van OCW, het consortium en de PROO, noch op initiatief van de PROO noch op initiatief van OCW. Hierdoor moest alle communicatie verlopen via de vertegenwoordiger van OCW in de PROO. In de praktijk betekende dit dat er alleen op incidentele basis contact was met de onderzoekcoördinatoren, veelal op eigen initiatief. Een meer gestructureerd overleg had de beleidsrelevantie van COOL mogelijk kunnen vergroten. Als illustratie kan hier dienen de rol van de voormalige PRIMA adviescommissie ${ }^{3}$ die elke 2-3 maanden bij elkaar kwam en waarin vertegenwoordigers zaten van $\mathrm{OCW}$, inspectie, SCP etc. Juist dit overleg verhoogde de beleidsrelevantie van het PRIMA onderzoek waardoor initiatieven werden ondernomen om aanvullende modules uit te zetten en nieuwe rapporten te maken.

Hoewel het vanuit historisch oogpunt logisch leek om COOL bij de PROO onder te brengen, was het beter geweest om ook de BOPO en later de PROBO er bij te betrekken om zo de beleidsrelevantie te vergroten. De PROBO en voorheen de BOPO hebben ook een beperkt aantal aanvullende onderzoeken uitgezet, maar het lijkt erop alsof op dit punt weinig afstemming met de PROO bestond.

\section{Het onderzoeksdesign}

Vóór COOL werden afzonderlijke cohorten gevolgd in PO (PRIMA) en in VO (VOCL). Het idee om leerlingen doorlopend te volgen in zowel PO als VO was gebaseerd op Bosker en Meijnen. ${ }^{4}$ In de oorspronkelijke offerte door GION werd het idee geopperd om regiosampling (nodale gebieden) te gebruiken om een link te leggen tussen COOL-PO en COOL-VO. Dit bleek echter uiteindelijk niet goed haalbaar vanwege het feit dat leerlingen te veel uitwaaieren over vervolgscholen. Dit was voor wat betreft de aansluiting PO-VO gedeeltelijk een gevolg van het feit dat men vanwege de continuïteit tussen PRIMA en COOL vasthield aan het idee om zoveel mogelijk uit te gaan van de oorspronkelijke PRIMA-scholen, zodat al niet van een echte regio-sampling sprake was. Met name bij het VO heeft dit geleid tot non-respons, omdat het voor VO-scholen niet interessant is om met een handvol leerlingen mee te doen. Hierdoor moest men scholen overtuigen

3 Overigens ontbrak een dergelijke adviescommissie voor VOCL.

4 Bosker en Meijnen (2004), Naar een geïntegreerde opzet van de onderwijscohorten. 
om met hele klassen mee te doen. De omvang van de toetsen was echter zodanig dat deze een hele schooldag in beslag nemen. Het is daarom niet vreemd dat scholen niet mee wilden doen. Maar het is ook de vraag of het idee van regio-sampling in aanvang wel realistisch was. Voor Pre-COOL is wel uitgegaan van regiosampling, maar ook daar is gebleken dat er sprake is van een grote uitwaaiering van kinderen bij de overgang van de voorschoolse voorziening naar de basisschool.

Achteraf gezien was het beter geweest wanneer na de eerste meting dit design voor het VO zou zijn aangepast. Men had er toen voor kunnen kiezen om - net als bij PRIMA en VOCL - te kiezen voor aparte cohorten in PO en VO. Nu zijn twee vervolgmetingen verricht die maar met moeite representatief te noemen zijn (zie ook de paragraaf over dataverzameling en respons en bijbehorende gegevens in appendix 2) en die in ieder geval niet het beoogde doel (namelijk leerlingen vanuit COOL-PO blijven volgen in COOL-VO) bereikt hebben.

Een extra complicatie in het design is het volgen van leerlingen via klassen. Dit geldt overigens alleen voor de testen en vragenlijsten. Alle leerlingen zijn altijd wel passief gevolgd in het onderwijsregister. Het probleem hierbij is de selectieve uitval op twee punten. Ten eerste kunnen scholen weigeren om aan vervolgmetingen mee te doen. Ten tweede is er individuele uitval van leerlingen door vertraging, schoolwisseling of voortijdig schoolverlaten. De vertraagde leerlingen in het VO werden niet getest bij de vervolgmetingen. Aanvankelijk werd dit wel geprobeerd, maar is er uiteindelijk van afgezien omdat de betreffende VO-scholen dit niet goed georganiseerd kregen. Het volgen van vertraagde leerlingen werd volgens de onderzoekers in het PO wel gedaan, namelijk in een aparte ronde 'verdwenen leerlingen'. Van alle leerlingen die zijn blijven zitten, verhuisd of naar speciaal onderwijs zijn verwezen werden toetsscores en leerlingprofiel opgevraagd bij de nieuwe scholen. Het is voor ons op dit moment niet duidelijk in hoeverre deze operatie ook voldoende succes heeft gehad, gelet op de grote uitval tussen groep 2 en groep 8 (zie appendix 2). Naar onze mening is de essentie van cohortonderzoek dat men de individuele leerlingen blijft volgen waar die ook zitten. Een data set die onvoldoende waarborgen heeft tegen selectieve uitval wordt aanzienlijk minder aantrekkelijk voor publicaties in wetenschappelijke tijdschriften. Voor de vervolgfase is het noodzakelijk om individuele leerlingen te blijven volgen, ook voor de testen en aanvullende metingen.

\section{Instrumenten PO}

Het is van belang om op te merken dat COOL-PO al voor een belangrijk deel werkt volgens het model waarbij zoveel mogelijk gebruik wordt gemaakt van bestaande data en aanvullingen plaats vinden op basis van extra metingen. De cognitieve prestaties worden ontleend aan het CITO LeerlingVolgSysteem (LVS) en de schoolgegevens van de CITO eindtoets. Deze worden voor COOL aangevuld met een aantal korte instrumenten: een IQ test in groep 5, een leerlingvragenlijst over zelfvertrouwen, welbevinden 
en taakmotivatie in groep 5 en 8, een test over burgerschapscompetenties ${ }^{5}$ in groep 8 , een leerlingprofiel in te vullen door de leerkracht in groep 2, 5 en 8 (vragen per leerling over werkhouding, gedrag, ouderlijke participatie, en de relatie leerkracht-leerling), een zorgprofiel in te vullen door de leerkracht in groepen 2, 5 en 8 (identificatie van het type zorgleerling; hoeft alleen ingevuld te worden wanneer de leerling aan bepaalde criteria voldoet), en een vragenlijst onder ouders.

Het is de vraag of de huidige instrumenten in COOL-PO allemaal en met dezelfde frequentie moeten blijven ingezet. Dat hangt deels af van de vraag of deze instrumenten gezien worden als voorspeller van latere uitkomsten (bv. de werkhouding, zoals beoordeeld door de leerkracht) of als uitkomst zelf (bv. cognitieve prestaties) en in hoeverre de metingen gezien kunnen worden als een stabiel kenmerk of als iets dat sterk verandert. Op basis van literatuurstudie en vergelijking met andere cohorten zou een verantwoorde selectie kunnen worden gemaakt van instrumenten die een goede predictieve validiteit hebben.

Er vindt sinds COOL geen dataverzameling meer plaats op het niveau van school- en klaskenmerken. Dat maakt enerzijds de belasting voor scholen minder zwaar, maar anderzijds de meerwaarde van $\mathrm{COOL}$ twijfelachtig. De enige gegevens die op school niveau gevraagd worden zijn die welke uit registers gehaald kunnen worden plus enkele aanvullende vragen (bv. is het een brede school etc.). Dit leidt ertoe dat COOL nauwelijks gebruikt kan worden om vragen te beantwoorden over variabelen die schooleffectiviteit zouden kunnen verklaren.

\section{Instrumenten VO}

Mede door de onduidelijkheid van de opzet (COOL was in opzet een dataverzamelingstraject in plaats van een project gestuurd door duidelijke onderzoeksvragen, zie ook de aanvraag) is er een grote batterij aan testen afgenomen. ${ }^{6}$ In het $3^{\mathrm{e}}$ leerjaar betreft dit:

- 1 lesuur leerlingvragenlijst (zie hieronder),

- 1 lesuur burgerschap of Engels,

- 1 lesuur IQ,

- 1 lesuur taalverzorging (grammatica, spelling),

- 1 lesuur leesvaardigheid en

- 1 lesuur rekenen.

5 Het is de vraag of de huidige meting van burgerschap ideaal is. Sommige onderzoekers vinden dat deze te weinig politiek is en verwijzen naar ICCS, dat een meer politieke conceptualisering van burgerschap heeft die beter aansluit bij de internationale literatuur. Aan de andere kant is een meer politieke invulling van het concept burgerschap voor jongere kinderen minder geschikt en is daarom bij COOL door de onderzoekers bewust gekozen voor een andere invulling.

6 Een deel van deze toetsen wordt door de onderzoekers als minder relevant gezien. Dat geldt bv. voor Taalverzorging. Dit moest echter meegenomen worden vanwege de invoering van de referentieniveaus. Navraag bij OCW leert echter dat dit wellicht door een betrokken ambtenaar bij de aanvang van $\mathrm{COOL}$ is aangegeven maar dat dit inmiddels niet herkend wordt als een onderdeel dat essentieel is voor het beleid. Ook de test Engels wordt door de onderzoekers als minder effectief gezien (te veel onderdelen). 
Bij de laatste meting is vanwege de lage respons van scholen bij sommige scholen gebruik gemaakt van de leerlingvolgsystemen die daar gebruikt worden (voorheen VAS, nu VVO volgsysteem voortgezet onderwijs).? Bij de aanvang van COOL was dat - anders dan in het PO - nog niet mogelijk. In het PO gebruikt 90\% van de scholen het CITO LVS. In het VO was dat in 2007 nog maar 20\%, inmiddels is dat $40 \%$. Dat maakt het makkelijker om ook die gegevens te gebruiken. Het VVO omvat Nederlands leesvaardigheid, Nederlands woordenschat, taalverzorging, Engels leesvaardigheid, Engels woordenschat en wiskunde en is beschikbaar voor groep 1-3 van het VO.

De huidige COOL testen in VO zijn niet adaptief, maar door de sortering in het VO naar niveau is dat ook niet nodig: men weet immers precies wie de moeilijke en wie de makkelijke vragen moet krijgen. Hoewel per niveau afzonderlijke testen worden afgenomen worden ze door CITO wel equivalent gemaakt. ${ }^{8}$ Ook de testen van VVO zijn equivalent.

Een ander issue is dat de COOL testen geen high stake testen zijn en er dus motivatie problemen zijn voor zowel scholen als leerlingen. De indruk bestaat bij de onderzoekers van het CITO dat de kwaliteit van de afname sterk verschilt tussen de scholen. Dat probleem speelt minder sterk bij de leerlingvolgsystemen.

Een aparte vraag is of je instrumenten kunt ontwikkelen die over de hele periode groei kunnen vaststellen. Voor de afzonderlijke periodes (PO en VO) is dat wel mogelijk en dat wordt ook door de volgsystemen beoogd. Maar er is een breuk tussen PO en VO omdat de domeinen die gemeten worden anders worden (wiskunde in plaats van rekenen). Ook binnen PO en VO kun je je afvragen of je echt groei kunt vaststellen omdat wat geleerd wordt ook verschuift: van bv. optellen naar breuken. Meet je dan nog hetzelfde? Wat altijd wel kan is rangordes vergelijken en kijken of eerdere metingen een goede voorspelling opleveren voor latere posities. Het is dan wel de vraag of dit voldoende is voor de beantwoording van de onderzoeksvragen die gesteld worden.

De leerlingvragenlijsten in leerjaar 3 en de eindexamenklas in HAVO en VWO bevatten een groot aantal instrumenten. De opzet hiervan varieert enigszins door de jaren. Opvallend is dat een groot deel van de instrumenten niet via DANS beschikbaar zijn omdat ze door de betreffende onderzoekers zelf zijn ingebracht en niet beschikbaar worden gesteld. Voor het meetjaar 2014 zijn de volgende instrumenten afgenomen met een onderscheid tussen COOL-instrumenten en 'eigen' instrumenten:

VO-3 COOL instrumenten:

- Welbevinden met docenten en welbevinden met klasgenoten (Peetsma, Wagenaar \& De Kat, 2001).

7 Dit levert wel equivaleer probleem op omdat er geen anker is tussen $\mathrm{COOL}$ en het volgsysteem. Door het verrichten van een equipercentiel equivalering of door bij de schatting van een IRT model aan te nemen dat de COOL-leerlingen en de volgsysteem-leerlingen uit dezelfde populatie komen, zijn er wel mogelijkheden om COOL en het volgsysteem aan elkaar te relateren. Er moet door CITO nog uitgezocht worden welke manier van equivaleren "het beste werkt".

8 De rapporten hierover zijn beschikbaar op de website www.cool5-18.nl. 
- Persoonlijkheid (selectie van 52 items uit de FFPl; Hendriks, 1999).

- Inventory of School Motivation (Mclnerney).

- Self-efficacy (PALS; Midgley et al., 2000).

- Taakoriëntatie. (Seegers, Van Putten, \& De Brabander, 2002).

VO-3 'eigen' instrumenten:

- School engagement (Schaufeli cs.) en school gerelateerde burnout (Finnen, m.n. Salmela-Aro).

- Academic Self Concept (Marsh); vakspecifiek.

- Value ratings (suggestie Marsh).

- Comparative evaluations (formaat afkomstig van Blanton, Buunk, Gibbons, \& Kuyper, 1999).

- Vijf items van de INCOM (sociale vergelijkings oriëntatie; Gibbons \& Buunk, 1999).

- Vakspecifieke Mastery en Performance oriëntatie.

- Achievement goals t.a.v. wiskunde.

- Self-handicapping behaviors (gesuggereerd door Peter Scheltinga).

- The Dark Triad (gesuggereerd door Pieternel, Jonason \& Webster, 2010).

- Neuro-psychologische items (ingebracht door Jelle Jolles, bepaalde versie van AMCKJ).

HAVO-5 en VWO-6 COOL instrumenten:

- Persoonlijkheid (selectie van 52 items uit de FFPI; Hendriks, 1999).

- Taakoriëntatie (Seegers, Van Putten, \& De Brabander, 2002).

- Welbevinden met klasgenoten (Peetsma, Wagenaar \& De Kat, 2001).

- Inventory of School Motivation (Mclnerney).

- Waargenomen autonomie (Veenstra \& Kuyper, 2004).

- Bijles.

- Schoolwerk in vakantie.

- Examenvoorbereiding.

- Examenvaardigheden.

- Schoolverzuim.

HAVO-5 en VWO-6 'eigen' instrumenten:

- School engagement (Schaufeli cs.) en school gerelateerde burnout (Finnen, m.n. Salmela-Aro).

- Opvoedstijl.

- Verschillende items over politieke en maatschappelijke participatie.

Verder wordt gebruik gemaakt van de eindexamencijfers (alleen CE). Deze eindexamencijfers zijn - anders dan veel mensen denken - niet allemaal bij CITO beschikbaar. Scholen zijn per examen verplicht om de gegevens van 5-10 leerlingen naar CITO te sturen. Scholen kunnen ook besluiten om de gegevens van alle leerlingen in te sturen, maar dat hoeft niet. 


\section{Dataverzameling}

De dataverzameling in het PO was bij de eerste meting gericht op de deelname van voormalige PRIMA scholen. Dit werd gedaan om de continuïteit tussen PRIMA en COOL te waarborgen. De groep 2 leerlingen uit het laatste PRIMA cohort (2004) kwamen zodoende in de eerste meting van COOL (2007) als groep 5 leerlingen 'te voorschijn', waardoor hun gang door het PO kon worden gevolgd. De respons onder die scholen was niet heel slecht, namelijk zo'n 57\% (zie appendix 2). Het bleek in COOL vooral moeilijk te zijn om vervangende scholen te vinden voor scholen die afhaakten. Onder de vervangende scholen was de respons aanvankelijk slechts $8,5 \%$ en dat liep later zelfs terug tot $2,5 \%$. Hier doemt het beeld op van een harde kern van scholen die in beginsel positief staat tegenover het onderzoek en een grote groep daarbuiten die slechts met grote moeite tot medewerking is te bewegen. Maar ook voor de harde kern geldt dat de cumulatieve paneluitval hoog is (in elke ronde 40-50\%) waardoor van de oorspronkelijke meting in 2007/08 van de 13.842 kinderen in groep 2 in de meting van 2013/14 maar 2,820 overblijven. Deels komt dat ook door uitval van individuele leerlingen door vertraging, versnelling of verhuizing naar een andere school.

In het VO was de deelname van scholen al vanaf het begin problematisch. Dit werd in latere metingen wel verbeterd door de inzet van speciale ambassadeurs (bv. oudleerkrachten of - inspecteurs) die ingezet werden om de medewerking van scholen te bevorderen. Niettemin bleek ook hier het probleem dat sommige VO-scholen afhaakten bij de vervolgmetingen. In totaal werden 2.141 van de 8.884 leerlingen uit leerjaar 3 teruggevonden in de vervolgmeting in HAVO 5 en VWO 6. Dit komt neer op ongeveer $60 \%$ respons van de oorspronkelijke HAVO/VWO leerlingen, wat op zichzelf niet slecht is. Daarbij moet wel bedacht worden dat slechts een klein deel van de leerlingen in leerjaar 3 tot de groep behoren van zogeheten target leerlingen, dat wil zeggen dat ze bij voorgaande metingen aan PRIMA of aan COOL-PO hebben meegedaan. Dat maakt dat de beoogde cohortopzet waarbij leerlingen van 5 tot 18 gevolgd worden zo goed als mislukt is.

Een probleem dat geconstateerd wordt door de onderzoekers is dat het niet voldoende is om schoolbesturen mee te krijgen, omdat scholen autonoom kunnen beslissen. En zelfs de medewerking van een schooldirecteur zegt nog niet alles, omdat docenten ook weer vrij autonoom zijn. De ervaring leert dat wanneer de directie e.e.a. intern niet goed gecommuniceerd heeft, dit later tot non-respons leidt.

Onze indruk is dat met name de belasting voor leerkrachten in het PO hoog is. De leerlingprofielen worden weliswaar door de onderzoekers de ' 3 minuten test' genoemd, maar in de praktijk moeten leerkrachten vaak 5 of meer minuten per leerling besteden om de lijsten in te vullen. Dat is een tijdsinvestering van ruim twee uur per klas. Hoewel hiervoor een zeer ruime onderzoeksperiode wordt gehanteerd (drie maanden) en leerkrachten het werk dus kunnen spreiden blijkt het toch moeilijk ze daarvoor te motiveren. Het lijkt erop dat dit verder teruggebracht kan worden door te focussen op die 
kenmerken die een hoge voorspelkracht hebben voor relevante uitkomsten (vast te stellen door huidige data te analyseren) en die kenmerken die bij voorkeur vroeg in de loopbaan gemeten zijn, zodat ze ook een rol kunnen spelen in het opstellen van risicoprofielen van leerlingen.

Verder is de belasting voor PO-scholen volgens de onderzoekers niet heel groot. Niettemin wordt het door scholen wel zo ervaren, omdat ze ook een rol spelen bij de dataverzameling. Scholen moeten namelijk ook de brieven meegeven aan de ouders, inzamelen, en de leerlingvragenlijsten afnemen. Het betrekken van de school bij de organisatie van de dataverzameling is wel goed vanwege het positieve effect op de respons van de oudervragenlijsten, maar de belasting voor de leerkracht is naar onze mening een ernstig probleem.

Bij het VO is de belasting voor scholen heel hoog. Gemiddeld duurt de toetsafname 6 lesuren (1 lesuur per toets). En de opbrengst voor de scholen is relatief gering. Scholen krijgen wel een instellingsrapport, maar ze krijgen dit type informatie ook wel via andere kanalen (dat geldt uitsluitend voor de scholen die gebruik maken van het VVO) en de indruk bestaat bij de onderzoekers dat de scholen weinig belang hechten aan deze terugkoppeling (hoewel sommige scholen wel degelijk enthousiast zijn over de informatie die ze vanuit COOL krijgen). De infrastructuur is er ook niet op ingericht om scholen meer maatwerk te leveren: dat maakt de kans dat de opbrengst hoger kan worden door meer met de scholen samen te werken (zie suggestie adviescommissie) erg gering is.

De indruk bestaat bij onder meer de vertegenwoordigers van OCW dat de belasting voor het veld ook aanmerkelijk teruggebracht zou kunnen worden door minder leerlingen te bevragen en het aantal instrumenten terug te brengen. Met een groot deel van de gegevens wordt door OCW niets of weinig gedaan en voor sommige vragen zou een steekproef onder een geringer aantal leerlingen volstaan. In de praktijk heeft men bij de uitvoering van $\mathrm{COOL}$ ook een deel van de instrumenten laten vallen om op die manier de belasting voor scholen te beperken. Dit heeft echter ook een prijs. Naarmate er minder interessante data verzameld worden, daalt ook de mogelijke opbrengst van het onderzoek, zowel voor beleid als wetenschap. Dit is de negatieve spiraal waar volgens ons $\mathrm{COOL}$ in gevangen zit.

\section{Privacy}

Om gebruik te kunnen maken van de gegevens van CITO-LVS is toestemming van de scholen nodig. Een deel van de scholen deelt deze gegevens met CITO om terugkoppeling te krijgen, maar er zijn ook andere software huizen die deze service bieden, bv. ESIS en PARNASSYS. Dat betekent dat scholen altijd op een of andere manier betrokken moeten zijn, wil je gebruik kunnen maken van LVS-gegevens. Voor het verstrekken van gegevens uit het LVS over leerlingen door de school is ook een vorm van 'informed consent' nodig van de ouders. Bij het PO krijgen ouders een brief waarin wordt gevraagd 
een eventueel bezwaar aan de school of aan de onderzoekers door te geven. Bij het VO bestaat er nu een online instrument dat ouders kunnen gebruiken: dat werkte volgens de onderzoekers beter dan de situatie waarin ouders konden mailen. Overigens hebben we tijdens onze gesprekken ook aanwijzingen gekregen dat het niet helemaal duidelijk is wat scholen mogen leveren en dat het geen uitgemaakte zaak is dat een 'informed consent' juridisch gezien nodig is. Het lijkt ons wenselijk dat OCW hierover in overleg treedt met deskundige juristen op dit terrein.

Probleem met de huidige wetgeving is dat voor leerlingen jonger dan 16 jaar de ouders toestemming moeten geven voor het verstrekken van de gegevens. Vanaf 16 jaar is toestemming van de leerling zelf nodig. Bij de toetsen in leerjaar 3 van het VO gaat het vaak om zowel 15- als 16-jarigen. Op dit moment wordt alleen aan de ouders toestemming gevraagd, maar formeel klopt dat dus niet.

Een ander mogelijk probleem is dat onderzoekers niet mogen beschikken over het onderwijsnummer. Dat betekent dat zij voor de koppeling met registerdata van het CBS, naam, adres, woonplaats plus geboortedata doorgeven, waarna CBS koppelt. Dat is weliswaar omslachtig, maar er is geen alternatief. Bovendien blijkt het in de praktijk redelijk goed te werken. Als directe levering aan het CBS mogelijk gemaakt wordt, kunnen de onderwijsnummers wél meegenomen worden.

\section{De rapportages en overige output}

De door PROO geïnitieerde praktijk om de dataverzameling en de basisrapportage te scheiden heeft een negatief gevolg. Voor het PO zijn er alleen technische rapporten zijn en geen inhoudelijk basisrapporten, waardoor COOL minder zichtbaar dan voorheen PRIMA. Voor het VO verschenen wel inhoudelijke basisrapporten, maar die komen relatief laat beschikbaar en hebben vooral een beschrijvend karakter. Het zou goed zijn om in de toekomst in ieder geval een inhoudelijk verslag met een duidelijke inhoudelijke focus toe te voegen bij de opdracht van dataverzameling. ${ }^{9}$ Direct daarna kunnen dan de data beschikbaar worden gesteld en een apart programma worden gemaakt voor verdere analyse dat dan open staat voor alle onderzoekers. Nu proberen de consortiumonderzoekers de meer inhoudelijke werkzaamheden uit te voeren via aanvullende opdrachten van bijvoorbeeld PROBO of OCW..$^{10}$ Dat kan leiden tot strategisch gedrag waarbij men probeert op een andere manier te profiteren van het feit dat men de data verzameld heeft. Op zich is dat niet erg en leidt het strategisch gedrag zelfs tot meer innovatief gebruik van de data, maar dan zouden onderzoekers buiten het consortium diezelfde mogelijkheden moeten krijgen. Die hebben dat nu niet.

9 Zo'n rapport zou bv. een aantal meer algemene beschrijvingen kunnen bevatten van de wijze waarop de prestaties en loopbanen van leerlingen zich ontwikkelen als ook een of meer thematische hoofdstukken, bv. gericht op een actueel beleidsthema. Het was oorspronkelijk ook de bedoeling om dit via de modules uit te voeren, maar die zijn nooit van de grond gekomen. Zie ook de paragraaf hieronder over'relevantie voor beleid'.

10 Ook werden de onderzoekers van het consortium rechtstreeks door opdrachtgevers gevraagd om aanvullend onderzoek te verrichten. 
Appendix 3 geeft een overzicht van de verschenen publicaties op basis van COOL (volgens de jaarlijkse opgave van onderzoekers aan PROO). Daarnaast hebben we aanvullend gegevens verzameld bij de instituten over lopend en afgesloten proefschriften. Daaruit blijkt dat in totaal 42 proefschriften zijn verschenen of gepland op basis van Pre-COOL, en er zijn proefschriftstudies verschenen of gepland op basis van COOL-PO en COOL-VO. Daarnaast zijn er 12 artikelen verschenen in internationale peer-reviewed tijdschriften (voornamelijk op basis van COOL-PO en COOL-VO) en 13 in Nederlandstalige peer-reviewed tijdschriften. Daarnaast is nog een groot aantal papers verschenen die in de fase zitten van submission. Voorts zijn ongeveer 30 beleidsrapporten verschenen in opdracht van uiteenlopende opdrachtgevers zoals OCW, onderwijsraad, BOPO en inspectie. Ook worden de data gebruikt door CPB, SCP en Inspectie, die daarover weer publiceren. Dat nuanceert toch aanmerkelijk het beeld dat er heerst rondom de opbrengst van COOL. Er is meer gebruik gemaakt van de data dan verondersteld wordt en ook de wetenschappelijke opbrengst is met 18 geplande of verschenen proefschriften bepaald niet gering. Naar onze indruk zou dit in de toekomst nog toe kunnen nemen wanneer de data gekoppeld worden aan registerdata (zowel latere onderwijsuitkomsten als bv. arbeidsmarktuitkomsten).

\section{Relevantie voor beleid}

Volgens de vertegenwoordigers van OCW is maar op beperkte schaal gebruik gemaakt van de gegevens uit het $\mathrm{COOL}$ onderzoek. Uitzonderingen betroffen volgens hen aanvullende rapportages over excellentie ${ }^{11}$, de evaluatie van schakelklassen, zittenblijven en de effecten van over- en onderadvisering. In het verleden werd relatief veel gebruik gemaakt van de PRIMA cohorten, maar dat is volgens de vertegenwoordigers van OCW met de komst van COOL-PO minder geworden. Via de BOPO/PROBO worden echter nog wel specifieke vragen uitgezet waarbij gebruik wordt gemaakt van COOL-PO. Van COOL-VO is volgens de vertegenwoordigers van OCW vrijwel geen gebruik gemaakt.

Niettemin laat het overzicht van Appendix 3 zien dat er wel degelijk meer beleidsrapporten zijn verschenen dan de vertegenwoordigers van OCW voor ogen hadden. Dit zou ook te maken kunnen hebben met gebrekkige communicatie binnen OCW. Volgens opgave van ITS/KI zijn er 16 projecten uitgevoerd op basis van de eerste en tweede COOL meting voor OCW, 8 voor NWO/BOPO, 4 voor diverse gemeenten, 3 voor de Inspectie, 2 voor de Onderwijsraad en 1 voor de PO-Raad. Daarmee komt men voor COOL-PO uit op een totaal van 34 additionele projecten. Bij COOL-VO loopt op dit moment volgens opgave van GION 2 aanvullende projecten in opdracht van de PROBO, 1 voor OCW en 1 op basis van een promotiebeurs voor leraren. Onze indruk is dat COOL, zeker het PO-gedeelte, wel degelijk meer relevantie heeft gehad voor de onderwijspraktijk dan door de beleidsmakers ervaren is.

11 Interessant is dat deze zijn uitgevoerd op VOCL data omdat bij COOL nog onvoldoende data beschikbaar waren. 
In dit verband wordt ook gewezen op het feit dat de beleidsvragen bij OCW verschoven zijn. In de tijd van PRIMA en VOCL was er veel aandacht voor de sociale ongelijkheid in onderwijsprestaties en werd het onderzoek vooral gericht op de bestrijding van onderwijsachterstanden. Nu ligt de aandacht veel meer op bijvoorbeeld passend onderwijs en bevordering van excellentie. Het is de vraag of de steekproefopzet van $\mathrm{COOL}$ daar goed bij past.

Een andere reden is dat bij de opzet van COOL werd uitgegaan van een 'kale' dataverzameling die aangevuld zou worden met modules die meer op specifieke onderzoeks- of beleidsvragen zou zijn gericht. Hoewel bij aanvang hiervoor ook geld was gereserveerd, is deze opzet nooit van de grond gekomen. Dat heeft het draagvlak voor COOL niet versterkt.

Eerder is al gewezen op het ontbreken van een goede overlegstructuur met beleidsmakers. Een meer gestructureerd overleg had de beleidsrelevantie van $\mathrm{COOL}$ mogelijk kunnen vergroten. De vertegenwoordigers van OCW geven daarnaast twee andere oorzaken aan voor de geringe opbrengst van COOL voor het beleid. Op de eerste plaats wordt door de verbetering van de onderwijsregisters al in een groot deel van de informatiebehoefte van OCW voorzien. Het gaat hierbij met name om in-, door- en uitstroomgegevens. Voorheen moesten deze ontleend worden aan de cohortonderzoeken, maar sinds enkele jaren kunnen deze beter en meer betrouwbaar ontleend worden aan de registers. Op de tweede plaats wordt gewezen op de grote vertraging waarmee rapporten worden opgeleverd. Dit had uitsluitend betrekking op de rapportages over COOL-VO die volgens OCW te laat komen om nog beleidsrelevantie te hebben. Een verklaring voor het feit dat de COOL-VO rapportages later beschikbaar zijn dan de COOL-PO rapportages komt door de onderzoekers deels door het feit dat bij COOL-VO veel eigen testen worden gebruikt die geëquivaleerd moeten worden. Ook de koppeling met registerdata kost extra tijd.

De vertegenwoordigers van OCW maken een uitzondering voor het COOL-speciaal onderzoek en de typering van zorgleerlingen in COOL-PO. Die voorziet wel in een duidelijke informatiebehoefte van OCW omdat goede informatie over zorgleerlingen niet in de registers zit. De scholen maken alleen een opgave of een leerling wordt aangemerkt als een leerling met "ontwikkelingsperspectief" (voorheen handelingsplan) zonder dat duidelijk is wat de precieze definitie is of om wat voor type zorgleerling het gaat. In COOL-PO en COOL-speciaal wordt hierin wel voorzien en de betreffende gegevens zijn van belang voor een evaluatie van de Wet Passend Onderwijs.

Ook Pre-COOL wordt potentieel als beleidsrelevant gezien. De belangrijkste overweging hierbij is dat voor een optimale cognitieve en niet-cognitieve ontwikkeling vroege interventies steeds belangrijker worden gevonden. Het beleid richt zich daarom steeds meer op de VVE-instellingen. Maar er zijn geen registerdata aanwezig op basis waarvan deze ontwikkeling in cognitieve en non-cognitieve prestaties van zeer jonge kinderen kan worden gemeten. 
Voor de specifieke evaluatie van landelijke beleidsmaatregelen wordt volgens de vertegenwoordigers van OCW nauwelijks gebruik gemaakt van COOL data (maar zie ook de nuancering hierboven). Hiervoor zijn specifiek opgezette evaluatiestudies volgens hen meer geschikt en dat gebeurt ook in toenemende mate (zie bv. de NRO call naar de evaluatie van beleidsmaatregelen in het MBO of de evaluatie van passend onderwijs). ${ }^{12}$ Daarnaast acht men het van belang dat ook meer gebruik wordt gemaakt van specifieke experimenten al wordt ook aangegeven dat die vaak niet mogelijk zijn voor de evaluatie van de grote beleidshervormingen. Dat betekent overigens niet dat cohortdata zoals COOL voor het beleid niet van belang zijn. Men zou kunnen zeggen dat voor sturingsvragen meer een beroep wordt gedaan op specifieke evaluatiestudies (zowel experimenten als verklarende evaluaties) en dat voor monitoring van de kwaliteit van het onderwijssysteem meer gebruik wordt gemaakt van cohortonderzoek of crosssectionele surveys.

\section{Beschikbaarheid van data}

De gegevens van COOL-PO zijn volgens de onderzoekers beschikbaar via DANS binnen een jaar na de start van de dataverzameling. Bij het $\mathrm{VO}$ deel duurde dat volgens de onderzoekers langer, namelijk zo'n anderhalf jaar na afronding van de dataverzameling. Voor een deel komt dat omdat bij COOL-VO veel meer data zelf verzameld worden (bv. de testen) waardoor meer tijd nodig is voor datamanagement en schaalanalyses. Niettemin geven de betreffende onderzoekers aan dat de doorlooptijd korter zou kunnen zijn.

Opvallend is dat de data van COOL-VO nu in overleg tussen GION en CBS via Remote Access beschikbaar worden gesteld. Voor COOL-PO is hier door PROO niet in voorzien in de afspraken met het $\mathrm{Kl}$, omdat bij aanvang van $\mathrm{COOL}$ er nog geen sprake was van koppeling van gegevens uit het onderwijsnummer met de data uit COOL-PO. Inmiddels is dat wel mogelijk en dat zou natuurlijk voor de waarde van de COOL-PO gegevens wel van belang zijn. Ook hier tekent zich een gebrek aan regie vanuit de PROO.

In het rapport van de adviescommissie wordt opgemerkt dat testgegevens niet op itemniveau beschikbaar zijn. Dit verwijt is echter niet helemaal terecht, althans voor het PO. De CITO-LVS gegevens worden immers niet op itemniveau ingevoerd door de leerkracht, maar alleen als eindscore. De gegevens voor de CITO eindtoetsen zijn via de registerbestanden beschikbaar, maar waarschijnlijk ook niet op item-niveau. Het CITO heeft deze gegevens wel, maar kan deze alleen beschikbaar stellen na goedkeuring van de scholen die eigenaar zijn van de data. Het CITO hanteert als regel dat de school actief toestemming moet geven voor het gebruik van de data. Daarnaast is passieve toestemming van de ouder/leerling gewenst ("in de geest van de WBP"). Voor 16-jarigen en ouderen moeten de leerlingen geïnformeerd worden en de mogelijkheid hebben om bezwaar te maken.

12 Daarbij moet echter aangetekend worden dat ook bij die evaluaties onder andere gebruik wordt gemaakt van COOL data. 
Van de eigen testen/instrumenten in COOL-PO (dat zijn er niet veel) zijn weliswaar uitsluitend de schaalwaarden via DANS beschikbaar, maar zijn de afzonderlijke items wel bij de onderzoekers te verkrijgen. Het zou volgens ons echter beter zijn wanneer ook die gegevens direct via DANS beschikbaar worden gesteld.

Voor de data in COOL-VO ligt de beschikbaarheid van data duidelijk anders. Hier zijn - naast de reguliere COOL instrumenten - veel extra data verzameld. ${ }^{13}$ De onderzoekers zijn inventief geweest in het gebruiken van COOL om additioneel wetenschappelijk interessante data te verzamelen. Dat valt weliswaar te prijzen, maar deze data zijn in feite verzameld met de reguliere middelen voor COOL (de dataverzameling zelf is immers het meest kostbaar). Er is vanuit de PROO in het geheel geen zicht op deze additionele dataverzameling, laat staan dat er goede afspraken zijn gemaakt over het ter beschikking stellen van deze data via DANS. Het is van belang dat NRO in de toekomst de regie houdt over de additionele dataverzamelingen en afspreekt dat deze binnen een redelijke periode - zeg 2 jaar na dataverzameling - aan DANS beschikbaar worden gesteld. Instituten die hieraan niet voldoen zouden ook geen toegang meer moeten krijgen tot actuele gekoppelde data.

Een aparte kwestie is de vraag of andere onderzoekers ook gebruik kunnen maken van de data om deze te kunnen koppelen aan andere data op schoolniveau. Met dit soort verzoeken zijn de onderzoekers van COOL-PO in het verleden naar eigen zeggen soepel omgegaan en zijn deze gegevens na toestemming van de scholen, en het tekenen van een geheimhoudingsverklaring en goedkeuring door NRO ter beschikking gesteld. Voor COOL-VO geldt iets vergelijkbaars. Onderzoekers die extra data willen verzamelen bij leerlingen of scholen dienen dit - conform afspraak met PROO - via de betrokken onderzoekers te laten verlopen. Niettemin is het volgens ons tamelijk lastig voor externe onderzoekers om aanvullende data te verzamelen. De beslissing hierover zou niet bij de betrokken consortium-onderzoekers moeten liggen, maar rechtstreeks bij NRO.

In het algemeen concluderen we dat het voor buitenstaanders niet makkelijk is om toegang tot de data te krijgen. Ook de data bij DANS, althans die van Pre-COOL, zijn niet zonder meer beschikbaar, omdat onderzoekers voorwaarden kunnen stellen aan de ter beschikking stelling (zie onze briefwisseling hierover in appendix 4).

13 Voor COOL-VO geldt dat voor alle vragenlijsten waarop geen auteursrechten zitten de itemscores ook zijn opgenomen in de bestanden. Uitzonderingen zijn bijvoorbeeld de NSCCT en FFPI, waarvan de items beschermd zijn. Itemscores van vragenlijsten waarop wel een auteursrecht ligt worden in overleg ter beschikking gesteld aan derden. Hetzelfde geldt voor de aanvullend verzamelde schalen. 



\section{3 \\ TOEKOMSTIG DESIGN}

\section{De vragen voor longitudinaal onderwijsonderzoek}

De opzet van $\mathrm{COOL}$ was vanaf aanvang om een databestand te maken dat voor velerlei doeleinden gebruikt kan worden. De onderzoekers hebben het dan ook als vreemd ervaren dat ze door de adviescommissie achteraf gevraagd werden welke vragen precies beantwoord moeten worden door COOL. Niettemin is dat wel legitiem, omdat het een houvast biedt welke kerndata in ieder geval verzameld moeten worden en welke eventueel aanvullend of met een lagere frequentie verzameld moeten worden. Het ontbreken van duidelijke onderzoeksvragen heeft er toe geleid dat er in COOL heel veel getest is zonder duidelijk doel.

Dat betekent overigens niet dat het zinvol is om heel gedetailleerde onderzoeksvragen te formuleren. Cohortonderzoeken zoals $\mathrm{COOL}$ dienen een breed doel en hebben bovendien een zeer lange termijn horizon (in de regel 20-30 jaar), mede omdat ook de lange termijn effecten van onderwijs gemeten moeten worden. Dat alleen al maakt dat de vragen die dergelijk onderzoek moet beantwoorden alleen heel breed geformuleerd kunnen worden. Die brede doelen van cohortonderzoek zijn: (1) hoe stromen leerlingen door/hoe presteren ze; en (2) welke verklaringen zijn daarvoor te geven?

Meer specifiek dient het longitudinale onderwijsonderzoek zicht te geven op de belangrijkste functies van het onderwijs: de kwalificatiefunctie, de selectiefunctie, de allocatiefunctie en de socialisatiefunctie. Bij de kwalificatiefunctie van het onderwijs gaat het om de vraag of het onderwijs de leerlingen heeft uitgerust met die competenties die relevant zijn voor de doorstroom naar vervolgopleidingen of de doorstroom naar de arbeidsmarkt. Hierbij ligt het accent niet alleen op cognitieve prestaties maar ook op niet-cognitieve prestaties (bijvoorbeeld leermotivatie). Bij de selectiefunctie gaat het om het beoordelen van de leerlingen op de aanwezige competenties en het op grond hiervan toewijzen aan verschillende onderwijsstromen of certificeren naar eindniveau. De maatschappelijke legitimering van de kwalificatiefunctie van het onderwijs is voor een belangrijk deel gelegen in de betrouwbaarheid waarmee het onderwijs deze selectiefunctie vervult en de gevolgen die dit heeft voor de toegankelijkheid van het onderwijs voor bepaalde groepen, bijvoorbeeld kinderen uit een achterstandsmilieu. De allocatiefunctie van het onderwijs betreft de vraag of het onderwijs de leerlingen/schoolverlaters 
op een adequate wijze toe leidt naar vervolgtrajecten, zowel in het onderwijs als op de arbeidsmarkt. En ten slotte gaat het bij de socialisatiefunctie om de vraag of leerlingen ook voldoende zijn toegerust om maatschappelijk volwaardig te participeren. Hierbij ligt het accent vooral op burgerschapscompetenties.

Het longitudinaal onderwijsonderzoek zou niet alleen antwoord moeten geven op de vraag of het onderwijs deze functies adequaat vervult en de efficiëntie waarmee dit gebeurt, maar zou ook inzicht moeten geven in de belangrijkste determinanten ervan. Hierbij gaat het niet alleen om de determinanten op individueel niveau (persoonlijke kenmerken, gezinskenmerken), maar ook om mogelijke determinanten op klasse- en schoolniveau. Deze laatsten bepalen immers de beleidsruimte waarmee het onderwijs kan worden verbeterd.

Ofschoon longitudinaal onderzoek alleen hierop nooit een afdoend antwoord kan geven (daarvoor zou het nodig zijn om aanvullend ook experimenteel onderzoek te doen), kan ze wel een bijdrage leveren door de juiste verklaringsvragen te stellen en deze systematisch en theorie-gestuurd te onderzoeken. Daarbij zal ook aandacht moeten zijn voor vraagstukken van causaliteit. In het verleden zijn die vraagstukken vaak onderbelicht gebleven of is te weinig gebruik gemaakt van het arsenaal van technieken (zoals IV, Dif-in-Dif, regression-discontinuity etc.) om deze causaliteitsvraag zo goed mogelijk te adresseren. Als het longitudinaal onderwijsonderzoek meer moet zijn dan een monitoring en beschrijving van onderwijsloopbanen, dan zal ook serieus werk gemaakt moeten worden van het ontwikkelen van goede theorieën en variabelen die deze theoretische concepten meten alsmede van het gebruik van up-to-date technieken om deze relaties goed te modelleren. Daarnaast blijft voor het meten van de effectiviteit van beleidsinterventies ook experimenteel onderzoek nodig. Het is van belang om dergelijk onderzoek beter te integreren met het 'reguliere' longitudinaal onderwijsonderzoek.

\section{Aansluiting internationaal onderzoek?}

De vraag is opgeworpen of het nieuw te starten longitudinale onderwijsonderzoek aan zou kunnen sluiten bij internationaal onderzoek, zoals PISA, ICCS, TIMMS, PIRLS of het nieuwe LSSDC initiatief. Deze internationale onderzoeken hebben in de regel een hoge impact, zijn van goede kwaliteit, en bieden veel meer mogelijkheden voor wetenschappelijke publicaties ${ }^{14}$. Ook de vertegenwoordigers van OCW geven aan dat ze deelname aan dergelijke onderzoeken van groot belang achten. Het is echter wel de vraag of dergelijke internationale onderzoeken gebruikt kunnen worden als de harde kern voor het nieuw op te zetten longitudinale onderwijsonderzoek of dat ze daarin op een andere manier moeten worden ingepast. Een probleem is dat dit type onderzoeken in de regel weinig flexibel is. De afzonderlijke onderzoeken zijn ook niet in staat om de veelheid aan vragen te beantwoorden die we hierboven hebben geschetst, doordat ze zich slechts op een domein richten (ICCS: burgerschap; TIMMS: rekenvaardigheden;

14 Deze hebben wel vaak betrekking op de internationale data en zijn relatief weinig gericht op het verdiepen van de Nederlandse data. Daar zou ook meer aandacht voor moeten zijn. 
PIRLS: taalvaardigheden; LSSDC: sociaal-emotionele ontwikkeling), of niet longitudinaal zijn (ICCS, PISA) of niet landelijk representatief (LSSDC). Een algemeen probleem bij de internationale toetsen die cognitieve prestaties meten is dat het geen high stake testen zijn (met daardoor lagere betrouwbaarheid) en bovendien nog niet als adaptieve testen zijn ontworpen, waardoor de uiteinden van de verdeling niet goed gemeten worden. De LVS toetsen beogen leerlingen wel individueel betrouwbaar te meten. In combinatie met een incompleet design zijn toetsen uit internationale studies dus minder geschikt voor koppeling met individuele indicatoren in andere bestanden.

Dat betekent dat de internationale onderzoeken eerder als aanvulling dan als vervanging moeten worden gezien voor het nationale longitudinale onderwijsonderzoek. Wel is het van belang om deze onderzoeken beter te integreren in de bestaande data infrastructuur en te koppelen aan gegevens over eerdere cognitieve prestaties (uit de leerlingvolgsystemen) en de latere uitkomsten (uit de registers).

\section{Onderzoeksdesign}

De cohorten die internationaal het meest toonaangevend zijn (bv. de British Youth Cohort Study BYC, de Effective Pre-School, Primary \& Secondary Education Study EPPSE, de National Educational Panel Study NEPS, of de National Longitudinal Survey of Youth NLSY) hebben een aantal kenmerken gemeen: ze starten op zeer jonge leeftijd (bij voorkeur al voor de leerplichtige leeftijd) en lopen lang door. In de voorgenomen opvolger van de BYC verwacht men dat de respondenten gemiddeld 115 jaar oud zullen worden en worden middelen gereserveerd om deelnemers tot ver na de pensionering te volgen. Natuurlijk is een longitudinaal onderwijsonderzoek primair gericht op de loopbaan in het initieel onderwijs, en ligt dus het accent op zeg 5- tot 25-jarigen, maar ook die grens vervaagt. Perioden van onderwijs worden meer en meer afgewisseld met perioden waarin andere activiteiten verricht worden (werk, reis, zorgtaken etc.). In het kader van Leven Lang Leren (zie Kamerbrief OCW) wordt het steeds belangrijker gevonden om zicht te krijgen op de vormen van formeel en niet-formeel leren die mensen ondernemen ná het verlaten van het initieel onderwijs. Bovendien is het van belang om zicht te houden op de korte en lange termijn uitkomsten van onderwijs, zoals een succesvolle integratie op de arbeidsmarkt of in de maatschappij. Dit betekent dat het onderzoeksdesign in ieder geval de mogelijkheid moet bieden om ook gegevens op wat latere leeftijd te verzamelen en dat de dataverzameling zich moet richten op het volgen van individuen en niet op het volgen van klassen of scholen.

Voor de nieuwe opzet willen we een onderscheid maken tussen de basis dataverzameling die vooral gericht is op het in kaart brengen van de onderwijspositie per jaar (beschikbaar in de onderwijsnummer bestanden van DUO), de leerlinggewichten (voor PO) en of de leerling in een Armoede Probleem Cumulatie (APC) gebied woont (voor VO, beide gegevens beschikbaar via DUO), en de ontwikkeling van cognitieve prestaties in het primair en voortgezet onderwijs die ontleend kunnen worden aan het op brede schaal opvragen bij scholen van de gegevens van: het LVS voor de ontwikkeling 
in cognitieve prestaties van leerjaar $3^{15}$ tot met leerjaar 8 in het PO, de CITO eindtoets ${ }^{16}$, het advies basisschool, het VVO of vergelijkbare leerlingvolgsystemen in het VO voor de ontwikkeling in cognitieve prestaties in leerjaar 1 tot en met leerjaar 3 in het VO en het eindexamen. Het zou aan te bevelen zijn wanneer alle scholen deze gegevens standaard zouden leveren. Door OCW is echter aangegeven dat een dergelijke verplichting op het moment politiek moeilijk ligt. Zoals eerder aangegeven gebruikt zo'n 90\% van de basisscholen het CITO-LVS. In het VO bedraagt dit zo'n 40\%. Ook de tussentijdse toets kan gebruikt worden als instrument om de cognitieve prestaties te meten. Met de mogelijke ${ }^{17}$ invoering van een verplichting tot leerlingvolgsystemen in het VO zal het aantal scholen dat VVO gebruikt toenemen, maar zullen er ook andere aanbieders op de markt komen. De verwachting van CITO is dat het wel mogelijk moet zijn om deze verschillende leerlingvolgsystemen te equivaleren. Een alternatief is om het te beperken tot het VVO van het CITO en de tussentijdse toets. De koppeling van de DUO gegevens en de gegevens over de cognitieve prestaties uit het LVS en VVO kan hetzij bij DUO hetzij bij het CBS plaatsvinden. Het zou aanbeveling verdienen wanneer de scholen ook basisinformatie over de opleiding van de ouders beschikbaar zouden stellen aan DUO. Deze gegevens worden nu wel verzameld om het leerlinggewicht te bepalen, maar worden niet apart verstrekt. Het verdient aanbeveling dat OCW overleg voert met het onderwijsveld om ook deze gegevens standaard beschikbaar te stellen. De gegevens kunnen door zowel DUO als CBS worden verrijkt met gegevens uit de Gemeentelijke Basisadministratie GBA (ouders gehuwd/gescheiden, geboorteland kind, geboorteland ouders, samenstelling huishouden, plaats in de kinderrij) alsmede met de gegevens van DUO over de onderwijspositie van de andere kinderen uit het gezin.

Met de koppeling van onderwijsloopbanen, cognitieve prestaties en achtergrondgegevens van de ouders en de overige kinderen uit het gezin, is al een eerste basisregistratie beschikbaar die gebruikt kan worden om een deel van de eerder genoemde onderzoeksvragen te beantwoorden. Deze gegevens kunnen verder worden verrijkt door het CBS door ze te koppelen aan andere registerdata voor de individuele leerlingen. Hierbij gaat het enerzijds om achtergrondgegevens van het gezin van de leerling (bv. inkomen ouders, vermogen ouders, ouders werkend/zelfstandig/uitkering, ouders eigen huis, WOZ waarde eigen huis), maar ook om aanvullende gegevens over de leerlingen zelf (registratiegegevens van de Stichting Perinatale Registratie Nederland (PRN) over geboortegewicht en APGAR score, gegevens van AWBZ of zorgverzekeraars over bv. medicijngebuik, ziekenhuisopnamen, gegevens van jeugdzorg, bureau HALT etc.). Onderzocht zou moeten worden of het mogelijk is ook andere gegevens van de GGD beschikbaar te krijgen, bijvoorbeeld de ontwikkeling in de eerste 6 jaren op basis van het Van Wiechenschema en mogelijk andere gegevens. Hiervoor zou eventueel een landelijk format moeten worden ontwikkeld.

15 Eventueel zou ook al de prestaties in leerjaar 1 en 2 meegenomen kunnen worden die betrekking hebben op rekenen en taal, maar die vormen geen doorlopende schaal met het LVS in groep 3 tot en met 8.

16 PPON lijkt vanwege de geringe frequentie minder voor de hand te liggen als mogelijk instrument. De CITO eindtoetsen meten ook meer onderdelen van de taal en rekenontwikkeling dan PPON.

17 Op dit moment is het wetsvoorstel hiertoe aangehouden omdat er zorgen zijn bij de Kamer over de belasting voor scholen. 
Wanneer het niet mogelijk is om de opleiding van de ouders via de scholen te achterhalen, is het ook mogelijk om deze te ontlenen aan het opleidingsniveauregister. Een mogelijk probleem is dat dit opleidingsniveauregister nog niet $100 \%$ dekkend is, maar in ieder geval kan vastgesteld worden of ze na 1995 een diploma in het HO hebben gehaald en/of ze na 2003 respectievelijk 2005 een diploma hebben behaald in het VO respectievelijk $M B O{ }^{18}$ Via de Enquête Beroepsbevolking (EBB) zouden deze gegevens aangevuld kunnen worden met gegevens over opleiding en beroep van de ouders. De EBB is een 1\% steekproef en omvat naar schatting jaarlijks informatie over de ouders van zo'n 1.900 leerlingen van een leeftijdscohort. Omdat de gegevens over meerdere jaren (bv. 10 jaar) gepoold kunnen worden zal van 8-9\% (ruwe schatting) van de leerlingen uit een bepaald leeftijdscohort het beroep van de ouders bekend zijn. Daarbij moet men er wel rekening mee houden dat mensen van beroep kunnen wisselen, zodat de informatie niet altijd up-to-date is. Voor opleiding ligt dit aanmerkelijk hoger vanwege de aanvulling uit de registerdata. Hier varieert de schatting van $55 \%$ van de ouders die op dit moment 35 jaar oud zijn tot 30\% van de ouders die op dit moment 55 jaar oud zijn. Deze percentages zullen elk jaar iets toenemen omdat het register voor jongere ouders wel redelijk dekkend is (met uitzondering van diploma's die behaald zijn in het buitenland of het niet-bekostigd onderwijs). Een risico is dat deze cijfers wel een oververtegenwoordiging geven van het aantal hoger opgeleiden. Dit kan ondervangen worden door voor degenen die niet in het register zitten aan te geven wat de waarschijnlijkheid is dat ze geen opleiding in het $\mathrm{HO}$ resp. VO of MBO hebben afgesloten. Dit kan door per opleidingstype leeftijdsgrenzen te bepalen waaronder of waarboven het onwaarschijnlijk is dat men een opleiding in het HO, VO of MBO heeft afgerond. Deze grenzen kunnen samen met de leeftijd van het individu en het tijdstip waarop het register is gestart gebruikt worden om te bepalen of een individu een opleiding kan hebben afgerond voordat het register gestart is of dat men kan aannemen dat het onwaarschijnlijk is dat men een dergelijke opleiding heeft afgerond nadat het register gestart is.

De registers van het CBS vormen eveneens de basis om leerlingen na het verlaten van het onderwijs te volgen: het gaat hier wederom om basale gegevens zoals werk, uitkering, inkomen, vermogen, partnerschap, kenmerken partner, kinderen, opleiding kinderen etc. Kenmerken van de transitie van school naar werk kunnen in aanvulling daarop in kaart gebracht worden door de gegevens te koppelen aan de schoolverlatersonderzoeken die het ROA jaarlijks uitvoert onder de schoolverlaters en afgestudeerden van VO, MBO, HBO, en WO (hier 2-jaarlijks in plaats van jaarlijks). Bij het MBO, HBO en WO is sprake van onderzoek onder vrijwel de gehele populatie, bij het VO is sprake van representatieve steekproef van ongeveer $4 \%$ in het HAVO/VWO en $10 \%$ in het VMBO.

De individuele leerlinggegevens uit de registerdata zouden vervolgens gekoppeld moeten worden op BRIN niveau aan registerdata van de scholen. Dit betreft in de eerste

18 De invoering van de registers was in 1995/96 voor HO, 2003/04 voor VO en 2005/06 voor MBO. Tellingen betreffen de situatie in oktober. Het jaar erop kan vastgesteld worden of iemand met of zonder diploma de opleiding verlaten heeft of nog steeds op de opleiding zit. De 1 oktober tellingen vormen ook de basis voor het in kaart brengen van de schoolloopbaan gegevens van de leerlingen. De data worden in maart van het daaropvolgend jaar opgeleverd. 
plaats de gegevens die via DUO verzameld worden over de leerkrachten (het voormalige IPTO bestand). Hierin zitten gegevens over bijvoorbeeld ziekteverzuim, verloop, vertrek uit het onderwijs, aanstellingsomvang en inschaling van de leerkrachten en directie van een school. Probleem is dat deze alleen op het niveau van de BRIN code aanwezig is en niet voor afzonderlijke vestigingen. Voor het PO is dat niet zo bezwaarlijk, maar voor de scholen in het VO kan dat nogal wat vertekening opleveren. Verder zijn enkele registerdata bekend bij inspectie en CBS over denominatie, schoolgrootte, leerlingaantallen, leerlingverloop en toetsscores. Ten slotte beschikt het CBS over registerbestanden van het UWV over onder andere aantal werknemers per school en beloning. Probleem bij dat laatste bestand is dat geen onderscheid gemaakt kan worden tussen onderwijsgevenden en niet-onderwijsgevenden en is daarom minder geschikt. Ten slotte verzamelt de inspectie 1 keer per vier jaar gegevens bij de scholen via de inspecteurs. In tegenstelling tot vroeger is deze dataverzameling nu echter meer maatwerk geworden. Dat betekent dat alleen die gegevens verzameld worden die voor het toezicht van die specifieke school van belang zijn (gerelateerd aan de kwaliteit van die school) en dus geen uniforme data opleveren. Dat vermindert de waarde voor koppeling aan de overige data.

Door de inspectie worden daarnaast echter jaarlijks zogenaamde stelselonderzoeken gedaan onder scholen. De inspectie hanteert hierbij een roulerend systeem zodat de belasting van scholen minder groot is. De steekproef omvat 400 scholen in het PO en 200 scholen in het VO. Hierin wordt wel meer systematische data verzameld die van belang zijn voor het nationaal cohortonderzoek, zoals onderwijstijd, lesroosters, lesmethoden, kwaliteit van de lessen, leerlingzorg, kwaliteitszorg etc. Het mooie van dit onderzoek is dat - omdat het uitgaat van de inspectie - de medewerking van scholen vrijwel integraal is. Deze dataverzameling zou de harde kern moeten vormen van de dataverzameling op het niveau van de scholen zodat ook vraagstellingen naar schooleffectiviteit beantwoord kunnen worden. Het zou gewenst zijn om met de inspectie in overleg te treden op welke wijze dit onderzoek voor een breder doel gebruikt kan worden. Gedacht kan worden aan een samenwerking tussen onderzoekers en inspecteurs om de juiste gegevens boven water te krijgen. Ook is het mogelijk dat aanvullend onderzoek (zie de modules hieronder) juist op deze scholen plaats vindt.

In onze visie vormt de basisregistratie samen met de onderzoeken van de inspectie de harde kern van het longitudinale onderwijsonderzoek. Deze zou vervolgens aangevuld kunnen worden met verschillende modules, die niet noodzakelijkerwijs hoeven te overlappen en die een meer beperkte looptijd hebben (bv. eenmalige metingen of metingen die een doorlooptijd hebben van maximaal 4 jaar). Het is aan NRO om in overleg met de 3 programmaraden en OCW te bepalen welke modules relevant zijn. Ter illustratie geven we de volgende voorbeelden:

- Module voorschoolse educatie. Deze module zou een voorzetting kunnen zijn van het huidige Pre-COOL onderzoek eveneens geënt op de cognitieve en sociaalemotionele ontwikkeling tot 5 jaar. In lijn met de oordelen van de onderzoekers zou het beter zijn om eerder te starten, bij de geboorte (of zelfs in de prenatale fase, zoals 
de gezondheidsstudie Generation $\mathrm{R}^{19}$ ). Hiervoor zou een aselecte steekproef kunnen worden getrokken bij consultatiebureaus. Om de effecten van VVE instellingen te onderzoeken zou het nodig zijn om deze basissteekproef, aan te vullen met extra leerlingen die vanaf 2-jarige leeftijd ingestroomd zijn in de VVE-instellingen.

- Module speciaal onderwijs. Voor een goede evaluatie van de wet op het passend onderwijs is het nodig dat gegevens beschikbaar zijn over het type zorgleerling. Deze gegevens zijn echter (nog) niet via registers beschikbaar. Het is waarschijnlijk wenselijk dat specifieke dataverzameling gericht op het speciaal onderwijs plaatsvindt. Dit zal mogelijk ook een pendant in het reguliere PO moeten hebben om zinvolle uitspraken te kunnen doen. Een alternatief is dat het Ministerie of de inspectie de scholen vraagt om de informatie over het type zorgleerlingen meer gestructureerd en volgens een landelijk format op te leveren. Daarbij zou gebruik kunnen worden gemaakt van het format dat in het kader van COOL-speciaal is ontwikkeld.

- Module sociaal-emotionele ontwikkeling. Er lijkt bij OCW behoefte te bestaan om longitudinaal onderzoek te verricht naar de sociaal-emotionele ontwikkeling van kinderen, zowel in het PO als het VO. Dit blijkt uit de interesse voor het OECD initiatief LSSDC. We onderschrijven het belang van het meten van niet-cognitieve vaardigheden..$^{20}$ Het is echter de vraag of het zinvol is om hiervoor aansluiting te zoeken bij het OECD initiatief. In de eerste plaats is het OECD initiatief gericht op het longitudinaal volgen van leerlingen in grote steden. In de documentatie voor het project ${ }^{21}$ is geen goede argumentatie te vinden waarom men zou kiezen voor een grote stad of regio als steekproefkader, anders dan dat het om praktische redenen handiger kan zijn om leerlingen op die manier te volgen. Op zijn minst zou het steekproefkader van de OECD aangevuld moeten worden met steekproeven van scholen uit de provincie om duidelijk zicht te krijgen op de grote verschillen die er in dit opzicht zijn tussen stad en platteland. Een tweede reden is dat longitudinaal onderzoek zeer belastend is voor scholen. Uit de ervaringen met COOL blijkt dat het moeizaam is om voldoende medewerking van scholen te krijgen, zeker omdat de studie ook veel inzet vraagt van leerkrachten (beoordelingen van leerlingen). Dit speelt des te meer omdat veel PO-scholen al instrumenten gebruiken om de sociaalemotionele ontwikkeling van leerlingen te volgen en het dus moeilijk wordt om de meerwaarde van het onderzoek aan te geven. We denken dat het verstandiger is om te kijken wat de mogelijkheden zijn van gebruik van bestaande instrumenten, met name het instrument VISEON van het CITO. Dat instrument is - net als de voorgenomen LSSDC - gebaseerd op het meten van de ontwikkeling in sociaal-emotionele ontwikkeling gebaseerd op de Big Five. ${ }^{22}$ Interessant is dat VISEON breed gebruikt

19 Dit is een onderzoek waarbij 10.000 kinderen in Rotterdam in hun ontwikkeling gevolgd worden, zie http:// www.generationr.nl/het-onderzoek.html.

20 Zie ook de CPB studie 'Investeringen in persoonlijke ontwikkeling verbeteren sociaaleconomische uitkomsten' door Borghans, Diris en Ter Weel (2014) en de OECD studie 'Fostering en Measuring Skills: Improving Cognitive and Non-Cognitive Skills to Promote Lifetime Success' van Kautz, Heckman, Diris, Ter Weel en Borghans (2014).

21 Zie de documentatie voor de Experts meeting OECD Longitudinal Study of Skills Development in Cities, gehouden van 2-3 februari in Den Haag.

22 Interessant in dit verband is dat VISEON om deze reden in de overzichtsstudie die het Kohnstamm instituut uitvoerde voor OCW als 'ongeschikt' instrument werd getypeerd, omdat het hier zou gaan om stabiele persoonskenmerken (Ledoux, Meijer, Van der Veen en Breetvelt, 2013, 'Meetinstrumenten voor sociale 
wordt door scholen: één op de zeven scholen in PO. Het instrument wordt momenteel herzien. CITO had ook een vergelijkbaar instrument voor het VO, STUDEON, dat echter minder breed gebruikt wordt en inmiddels niet meer wordt verkocht. Het voordeel van VISEON is dat de betreffende data ook gekoppeld kunnen worden aan de gegevens uit het LVS zodat ook de relatie met de cognitieve ontwikkeling goed in beeld kan worden gebracht.

- Module burgerschapscompetenties. Op zich is het thema van burgerschap een belangrijk en opkomend thema niet alleen in de wetenschap maar ook in de beleidsdiscussie, zoals de politieke discussies na de recente aanslagen in Parijs en Denemarken weer eens aantonen. Het is wel de vraag of de huidige meting van burgerschap de meest ideale is. Sommige onderzoekers vinden dat deze te weinig politiek is en verwijzen naar ICCS, dat een meer politieke conceptualisering van burgerschap heeft die beter aansluit bij de internationale literatuur. Anderzijds is een meer politieke invulling van het burgerschapsbegrip minder geschikt voor het PO. Wanneer men een longitudinale meting wil hebben van burgerschapscompetenties dan is het belangrijk om eenzelfde instrument in het PO en het VO te gebruiken. Analyses op basis van COOL data tonen aan dat burgerschapsverschillen in het VO ook al aanwezig waren in het PO. Dit onderstreept het belang van een longitudinale meting.

- Module keuze vervolgonderwijs. Een belangrijk terrein betreft de keuzes voor vervolgonderwijs. Er zijn veel aanwijzingen dat dit proces verder geoptimaliseerd zou kunnen worden, om latere studie-uitval of spijt van de gekozen opleiding te voorkomen. Dit type onderzoek zou in samenhang met kleinschalige experimenten kunnen worden opgezet die erop gericht zijn om het proces van studie- en beroepskeuze te verbeteren.

- Internationale modules. Nederland heeft een sterke traditie in het participeren in internationaal vergelijkend onderzoek zoals PISA, TIMMS, PIRLS, ICCS en PIAAC. Deze onderzoeken worden ook van groot belang geacht voor het beleid en vanuit OCW is aangegeven dat deze onderzoeken belangrijker zijn dan COOL voor het vaststellen van de cognitieve prestaties. Deze onderzoeken zouden echter een belangrijke nationale meerwaarde krijgen wanneer ze gekoppeld kunnen worden aan de eerder genoemde basisregistratie. Daardoor kunnen de betreffende uitkomstmaten gerelateerd worden aan de eerdere ontwikkeling in cognitieve prestaties alsmede aan latere uitkomstmaten (vergelijk bijvoorbeeld de inbedding van PISA in longitudinale onderzoeken in de VS en Canada). De mogelijke koppelingen van deze data zijn - met uitzondering van PIAAC - op dit moment nog niet mogelijk. De PISA-gegevens zijn anoniem, en de leerling gegevens mogen volgens CITO niet bewaard worden van de OESO. In TIMSS en PIRLS (UT) worden geen leerlingen maar scholen getrokken; alleen de leerkracht weet om welke leerling het gaat. Bij niet-anonieme verwerking zou toestemming moeten worden gevraagd aan de ouders. De betreffende onder-

competenties, metacognitie en advanced skills', p. 40 en 137). Dit lijkt echter te berusten op een wat verouderde visie op de plasticiteit van persoonlijkheidskenmerken. Tegenwoordig wordt aangenomen dat deze nog tot in de volwassenheid te ontwikkelen zijn. Bovendien gaat ook het LSSDC design uit van socialeemotionele skills die ondergebracht kunnen worden in de Big Five taxonomie. 
zoekers vinden het voor de respons essentieel dat de anonimiteit is gegarandeerd. Wij betwijfelen dat. De ervaring met PIAAC heeft geleerd dat de non-respons als gevolg van informed consent door de deelnemers vrij gering is. Ook de ervaring met $\mathrm{COOL}$ is in dat opzicht geruststellend: vrijwel alle ouders geven toestemming om de gegevens van het LVS te gebruiken. Het heeft dus alles te maken met de wijze waarop de deelnemers geïnformeerd worden hierover. Hierover zal overleg moeten plaatsvinden tussen het NRO, OCW en de betrokken onderzoekers.

- Modules vervolgonderwijs: Door OCW is aangegeven dat er geen behoefte is aan een aparte modules in het MBO of HO. Dit komt voor een belangrijk deel omdat hierin al door lopend onderzoek wordt voorzien, zoals de Nationale Studenten Enquête. Het is echter van belang om ook deze onderzoeken te zien als een module in het nationaal onderwijsonderzoek en de meerwaarde ervan te vergoten door ze te koppelen aan registerdata.

\section{Organisatie}

Er moet een duidelijke structuur komen waarbij de coördinatie over het geheel van de basisregistratie en de aanvullende modules onder directe verantwoordelijkheid van de NRO valt. Idealiter zou dit de vorm van een klein instituut moeten hebben dat binnen NRO fungeert. ${ }^{23}$ Het zou moeten gaan om een nationale coördinator die bijvoorbeeld een 0,5 fte aanstelling heeft, aangevuld met een kleine staf. Deze nationale coördinator moet aangesteld worden voor de duur van minimaal 5 jaar en voldoende gezag hebben om effectief met de betrokken partijen (de programmaraden van NRO, OCW, CBS, CITO, DUO, Inspectie, DANS, uitvoerende onderzoeksinstituten etc.) te kunnen onderhandelen.

Het is niet gewenst dat de aansturing van dit instituut onder verantwoordelijkheid van de PROO valt, omdat het nationale longitudinale onderwijsonderzoek niet alleen wetenschappelijke doelstellingen heeft. Gelet op de centrale betekenis van de data voor zowel fundamenteel, beleidsgericht als praktisch onderzoek, zou dit ondergebracht moeten worden bij de overkoepelende programmaraad OPRO. Voor het draagvlak van het onderzoek en de wetenschappelijke verankering is het gewenst dat deze aansturing binnen OPRO bij twee aparte commissies wordt ondergebracht waarin vertegenwoordigers van wetenschap, beleid en de scholen zitten: een beleidscommissie en een wetenschappelijke adviesgroep. De beleidscommissie dient vooral te kijken naar de mogelijkheden voor beleidsgericht onderzoek, dient (via de drie programmaraden) opdrachten uit te zetten, en is verantwoordelijk voor de begeleiding en disseminatie van deze onderzoeken. Deze beleidscommissie zou bv. 3-4 maal per jaar bijeen kunnen komen. De wetenschappelijke adviesgroep dient het gehele proces van dataverzameling, de te gebruiken instrumenten, de opbrengsten etc. te bewaken vanuit wetenschappelijk

23 Men zou ook kunnen overwegen om deze functie bij een onderzoeksinstituut of een andere organisatie onder te brengen. Dat leidt echter tot meer afstemmingsproblemen en ook tot een te machtige positie voor het betrokken instituut of organisatie. De regie voor het longitudinale onderwijsonderzoek moet liggen bij het Nationaal Regieorgaan Onderwijsonderzoek (de naam zegt het al). 
oogpunt en ook voorstellen te doen voor verder wetenschappelijk onderzoek via de PROO. Deze wetenschappelijke adviesgroep zou bv. twee keer per jaar bijeen kunnen komen.

Van meet af aan moet ook de rol van CBS, CITO, DUO en Inspectie duidelijk gedefinieerd worden. Zij vormen de harde kern van het toekomstig onderwijsonderzoek en dienen bij de opzet en verdere uitwerking nauw betrokken te worden. De rol van CBS zou vooral gelegen moeten zijn in de koppeling van de bestanden aan relevante registerdata. DUO is verantwoordelijk voor de aanlevering van schoolloopbaangegevens en examengegevens en kan ook een deel van de koppeling verzorgen met data uit GBA en gegevens van CITO. CITO zou verantwoordelijk moeten zijn voor het advies over de toetsen die de ontwikkeling van cognitieve prestaties meten gedurende het primair en voortgezet onderwijs, te ontlenen aan de leerlingvolgsystemen en de CITO eindtoetsen en de equivalering daarvan zowel over verschillende schooltypen als over de tijd. De Inspectie is verantwoordelijk voor de reguliere dataverzameling onder scholen (gegevens op schoolniveau) en de aanvullende data uit registerbestanden zoals de voormalige IPTO.

Het CBS zou volgens ons een cruciale rol moeten vervullen in dit geheel. Dat betekent wel dat er duidelijke en heldere afspraken gemaakt moeten worden tussen NRO en CBS. De ervaring met het CBS is dat de oplevering van data soms traag verloopt en dat er hoge kosten verbonden kunnen zijn voor individuele onderzoekers om data te kunnen gebruiken (bv. de ter beschikking stelling via Remote Acess). Deels komt dit ook omdat het onderhoud van cohorten op dit moment geen prioriteit heeft bij het CBS (zie ook hoofdstuk 4) en er niet meer een vast team van onderzoekers aan de cohort data werkt. Het lijkt ons van belang dat NRO middelen ter beschikking stelt om 1 of 2 onderzoekers fulltime bij het CBS aan de nationale dataverzameling (inclusief datamanagement, koppeling, beschikbaarstelling van databestanden, onderhoud van 'oude' cohorten etc.) te laten werken. Dit moet ook opgenomen worden in de lange-termijn werkplannen van het CBS en de betreffende onderzoekers zouden rechtsreeks door de nationale coördinator aangestuurd moeten worden waar het de concrete werkzaamheden betreft (vergelijk de constructie die CBS hierover heeft met betrekking tot de landelijke Jeugdmonitor die in opdracht van VWS wordt uitgevoerd). NRO dient ook standaard afspraken te maken met het CBS over de maximale kosten die in rekening mogen worden gebracht voor het ter beschikkingstelling van de cohort data via Remote Access (omdat deze immers al voor een deel betaald worden via de rechtstreekse financiering).

Zoals eerder aangegeven kan een deel van de benodigde data ook door DUO gekoppeld worden en beschikbaar worden gesteld. Dit betreft de harde kern van de basisregistratie met daarin alle gegevens over de onderwijsloopbanen, de examengegevens en de aanvullende gegevens uit het GBA. Deze gegevens kunnen door DUO gekoppeld worden aan de gegevens van CITO over de cognitieve prestaties. Het voordeel van deze constructie kan zijn dat de data sneller geleverd worden en bovendien aan minder restricties onderhevig zijn dan bij de route via het CBS. Het is in dat geval wel van belang dat de koppeling plaatsvindt onder auspiciën van NRO en dat de rol van DUO uitsluitend 
bestaat uit het verrichten van de technische koppeling. Op die manier kan de vrees bij scholen weggenomen worden dat individuele gegevens over de cognitieve prestaties bij OCW terecht zullen komen.

\section{Dataverzameling}

Het is heel belangrijk voor de kwaliteit en representativiteit van de data, dat de bereidheid van scholen om mee te werken vergroot wordt. Men zou er aan kunnen denken om scholen te verplichten aan dit soort dataverzamelingen mee te werken. Deze verplichting zou kunnen gelden voor zowel de internationale onderzoeken PISA, TIMMS, PIRLS, ICCS, als de overige modules voor de nationale dataverzameling. Zoals eerder aangegeven is het wetsvoorstel hierover aangehouden, omdat de Tweede Kamer bezorgd is voor overbelasting van scholen. Dat maakt het lastiger om deze route te bewandelen. Bovendien is het de vraag of dit ook de beste wijze is om scholen te bewegen mee te doen. Naast de 'stok' is ook de 'wortel'van belang, met andere woorden scholen moeten ook meer verleid gaan worden om mee te doen. Daarvoor is het belangrijk dat ook het veld zelf sterker betrokken wordt bij de opzet en vormgeving van verschillende modules. De NRO kan hierin een belangrijke rol spelen door in overleg tussen OCW, NRO en schoolbesturen een sterker draagvlak te creëren om met deze centrale onderzoeken mee te doen. Denkbaar is ook dat scholen op een of andere manier 'beloond' worden door OCW of Inspectie wanneer ze kunnen aantonen dat ze door deelname aan het nationaal onderwijsonderzoek hun kwaliteitsbewaking verbeteren. Daar moet het betreffende onderzoek dan ook de mogelijkheden voor bieden door tijdig relevante informatie terug te koppelen. In Vlaanderen wordt bv. over TIMMS eerder terug gerapporteerd aan scholen dan in Nederland. Dat is weliswaar in strijd met de internationale afspraken, maar bevordert wel de relevantie voor de deelnemende scholen.

Daarbij is het belangrijk om een aantal zaken goed voor ogen te houden. Onderzoeken en modules moeten in ieder geval deels aansluiten bij datgene dat het veld belangrijk vindt. Met andere woorden, het onderzoek zal altijd een balans moeten zijn tussen datgene dat vanuit wetenschappelijke optiek van belang is, datgene dat vanuit beleidsoptiek van belang is en datgene dat voor de onderwijspraktijk van belang is. De OPRO is bij uitstek in staat om te bewaken dat deze drie invalshoeken voldoende in balans zijn.

Daarnaast is het van belang dat het veld niet onnodig belast wordt. De voorgestelde opzet met een harde kern in de basisregistratie aangevuld met specifieke modules die meer gericht zijn en bij een kleinere steekproef kunnen worden afgenomen, maakt al dat het veld veel minder belast zal worden dan in de huidige opzet. Door de coördinatie hiervan bij NRO te leggen kan voorkomen worden dat sommige scholen teveel belast worden en kan een gelijkmatiger verdeling van de onderzoeksdruk over de tijd plaats vinden. Dit is nodig omdat er sprake is van een overvoerde markt (deels door de overheid gewild vanwege de evidence-based policy) waarbij er veel vragen liggen bij scholen om mee te werken aan onderzoek. Door een goed roulatieschema op te stellen 
(taak van de nationale coördinator in nauw overleg met de inspectie) kan de belasting voor scholen relatief beperkt worden. Uiteraard moet het wel altijd mogelijk zijn voor scholen om op vrijwillige basis mee te doen met de onderzoeken ook als ze niet in de basissteekproef vallen.

\section{Ontsluiting van de data}

Een ander probleem is dat de gegevens die o dit moment via DANS beschikbaar worden gesteld veel minder bruikbaar zijn dan de originele gegevens die door CBS via Remote Access ter beschikking worden gesteld. Het is belangrijk dat de data veel sneller beschikbaar komen voor wetenschappelijke doeleinden. Een goed voorbeeld betreft de praktijk van PISA en andere OECD onderzoeken, waarbij goede public use files (micro-data) beschikbaar worden gesteld via de website vanaf het moment dat het eerste rapport gepubliceerd wordt.

Op dit moment wordt een onderscheid gemaakt tussen 'veilige' publieke bestanden die via DANS beschikbaar worden gesteld aan iedereen en meer gedetailleerde wetenschappelijke bestanden die door CBS via Remote Access beschikbaar worden gesteld. Appendix 5 geeft het beleid van het CBS weer. . Denkbaar is dat NRO zelf een tussenweg creëert door de data die onder haar auspiciën worden verzameld meer gedetailleerd beschikbaar te stellen onder stringente voorwaarden. Dat zou kunnen door DUO de technische koppeling te laten verzorgen van haar eigen gegevens, de data van GBA, gegevens van CITO of andere leerlingvolgsystemen, de data van de inspectie en eventuele data uit de modules. Na koppeling wordt dit bestand - geanonimiseerd op persoonsniveau, maar inclusief BRIN-code - ter beschikking gesteld van NRO en wordt het gekoppelde bestand bij DUO weer vernietigd. NRO kan het bestand ter beschikking stellen aan onderzoekers die voor NRO onderzoek uitvoeren. Omdat het gaat om een zeer gedetailleerd bestand waarbij het risico bestaat op onthulling van individuele gegevens, zou NRO hierover met de betreffende onderzoekers goede afspraken moeten maken om de privacy te waarborgen. In plaats van de outputcontrole zoals die nu plaatsvindt door CBS, is het waarschijnlijk voldoende om het management van de betreffende instituten of vakgroepen hierover een contract te laten tekenen. Hierin kan een aantal afschrikwekkende clausules worden opgenomen, zoals toekomstige uitsluiting van NRO-onderzoek bij overtreding van de privacy-regels.

NRO zal ook verantwoordelijk moeten worden voor het datamanagement. Een van de belangrijkste zaken betreft het reconstrueren van schoolloopbanen op basis van het onderwijsnummer. Het maken van schoolloopbanen is meer dan het simpelweg achter elkaar plakken van de opeenvolgende onderwijsposities. In de registerdata zitten inconsistenties, fouten, of ontbrekende waarnemingen die op plausibiliteit moeten worden gecontroleerd en waarbij zo nodig missende waarden worden geïmputeerd. Voor de kernvariabelen in het bestand zal NRO opdracht moeten geven aan een onderzoeksinstituut of aan het CBS om een opgeschoond bestand op te leveren. Het is ook denkbaar dat dit instituut voor de verschillende variabelen in het bestand een kwaliteitskeurmerk 
geeft: bv 1 ster voor die data die ongecontroleerd zijn tot 4 sterren voor data die volledig zijn gecheckt. 



\section{4 \\ ONTSLUITING EN ONDERHOUD BESTAANDE GEGEVENS}

Het is belangrijk om de bestaande praktijk van het cohort-onderzoek te evalueren en te komen tot een duurzame vorm van dataverzameling voor de toekomst. Minstens zo belangrijk is echter om na te gaan op welke wijze de bestaande data ontsloten en geactualiseerd kunnen worden. Op dat punt ontbreekt het aan alle regie. Dit heeft een aantal oorzaken:

- Bij de oudste cohorten (Noord-Brabant, 1952; Van Jaar tot Jaar, 1965; het Groningencohort, 1972; het Enschede-cohort, 1964) ontbreekt het eigenaarschap en het is onduidelijk of en zo ja op welke wijze deze cohorten nog geactualiseerd zouden kunnen worden. Interessant is dat het oorspronkelijke Noord-Brabant cohort door een consortium van economen en sociologen in 1983 en 1993 weer opnieuw benaderd is om de lange-termijn effecten vast te stellen. De meeste van deze gegevens zijn aanwezig bij DANS.

- De CBS-cohorten SMVO (1977), SLVO (1983), en VOCL 1989 zijn ontsloten via DANS. Deze cohorten zijn bovendien in een samenwerking tussen CBS en ROA gekoppeld aan registerdata zodat de oorspronkelijke respondenten ook gevolgd kunnen worden via de registers. Dat biedt de mogelijkheid om niet alleen lange-termijn effecten bij de primaire respondenten vast te stellen, maar ook te kijken hoe deze zich verhouden tot relevante anderen (overige kinderen in het gezin, buurt, school). Het probleem is dat het CBS het onderhouden van de cohorten op dit moment niet meer ziet als een kerntaak en dat daarmee kennis en mogelijkheden verloren gaan. Sinds vorig jaar is de capaciteit voor het onderhouden van cohorten tot vrijwel nul gereduceerd. Dit is een ernstige bedreiging van de waarschijnlijk belangrijkste databron die we op dit punt hebben.

- De VOCL cohorten 1993 en 1999 zijn in samenwerking tussen GION en CBS tot stand gekomen. Voor deze cohorten geldt hetzelfde als voor de oudere cohorten, met als toevoeging dat belangrijke aanvullende dataverzamelingen die verricht zijn door het GION (bv. naar vriendschapsrelaties, Big Five etc.) nooit door GION ter beschikking zijn gesteld aan derden. Aangezien ook deze data in het kader van de reguliere VOCL zijn verzameld (en dus met middelen van NWO), is het zeer gewenst en volstrekt redelijk dat deze aanvullende dataverzamelingen alsnog aan de publiek beschikbare datafiles en aan de via remote access beschikbare bestanden worden toegevoegd. Bovendien zou er beter datamanagement moeten plaatsvinden op de kernvariabelen in het bestand. Ter illustratie. In een onderzoek voor de Commissie 
Dijsselbloem is een simpele analyse uitgevoerd waarbij het effect van opleidingsniveau van de ouders, basisschooladvies en de score op de CITO-entreetoets op de keuze van type voortgezet onderwijs na de brugperiode onderzocht is. ${ }^{25}$ Doordat voor grote groepen leerlingen informatie op één of meerdere variabelen ontbraken, bleven er in de analyse van het oorspronkelijke aantal van ongeveer 20.000 leerlingen in VOCL89 zo'n 16.500 over, in VOCL93 zo'n 15.000 en in VOCL99 zo'n 13.000. Met andere woorden, bij de kernvariabelen in het bestand zijn er teveel missende waarden. Hier had indertijd door GION meer aandacht moeten worden besteed om deze informatie (bv basisschooladvies) boven tafel te krijgen. Maar ook in de schoolloopbaangegevens zitten veel missende waarden. Bij de overgang van VOCL1989 naar VOCl1993 is meer gebruik gemaakt van registerdata om leerlingen te volgen in hun loopbaan. Er zitten echter 'gaten' in de loopbaan deels omdat de registerdata nog niet optimaal waren, deels door tegenstrijdige informatie over de onderwijspositie. Nu wordt het aan individuele onderzoekers overgelaten om oplossingen te verzinnen voor het 'repareren' van de loopbaan. Het is gewenst dat dit op een uniforme wijze gebeurd door het CBS zelf. ${ }^{26}$

- De PRIMA cohorten zijn primair verzameld door ITS en KI. De data zijn beschikbaar gesteld bij WSA en later DANS.

Deze databronnen zijn potentiële goudmijnen ${ }^{27}$, maar die worden niet bewaakt omdat geen enkele organisatie daarvoor verantwoordelijk is: CBS ziet het niet als haar taak, DANS heeft alleen een archieffunctie en geen actieve ontsluitingsfunctie, en de afzonderlijke instituten hebben geen incentive om de data voor derden te ontsluiten. Het is van belang dat de NRO middelen reserveert om een 'nationale schatbewaker' aan te stellen. Deze 'schatbewaker' wordt verantwoordelijk voor het verzamelen, ontsluiten en actualiseren van alle bestaande longitudinale onderwijsdata. De functie zou ondergebracht moeten worden bij het CBS in nauwe samenspraak met NRO. Onderdeel van de taak is ook het beschikbaar stellen van documentatie, het zorgdragen voor geïntegreerde bestanden van opeenvolgende cohorten, uniformering van codering en de actualisering en verrijking van de data met registerdata.

25 Zie L. Borghans, R. van der Velden, C. Büchner, J. Coenen, C. Meng (2008), Het meten van onderwijskwaliteit en de effecten van recente onderwijsvernieuwingen, In: Commissie Parlementair Onderzoek Onderwijsvernieuwingen, Tijd voor Onderwijs, Deelrapport IV, Den Haag: SDU, pp. 3-114.

26 Daarbij dienen uiteraard ook de oorspronkelijke data intact te blijven, zodat externe onderzoekers ook eigen keuzes kunnen maken bij de constructie van de nieuwe variabelen.

27 Zie bijvoorbeeld de proefschriften van Traag (2012), Büchner (2013) en Humburg (2014) die gebruik hebben gemaakt van gekoppelde databestanden van SMVO, SLVO, en de VOCL cohorten met de registerdata van het CBS om te kijken naar de effecten van bv. voortijdig schoolverlaten op criminaliteit, cognitieve prestaties en inkomen, veranderingen in de primaire en secundaire effecten van sociale stratificatie, persoonlijkheid en studiekeuze etc. 


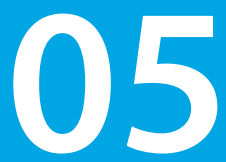

\section{SAMENVATTING EN CONCLUSIE}

OCW en NRO hebben een gezamenlijke vervolgopdracht gegeven aan Rolf van der Velden (UM/ROA) en Han van der Maas (UvA) om een advies uit te brengen over de toekomst van het cohortonderzoek. Directe aanleiding hiervoor is het feit dat de subsidieperiode voor het lopende cohortonderzoek COOL in 2016 afloopt.

Om een goed advies te kunnen uitbrengen over de toekomst van het cohortonderzoek hebben we gemeend dat het ook belangrijk is om een goed inzicht te krijgen in het huidige COOL onderzoek. Daarvoor hebben we met een groot aantal betrokkenen gepraat en relevante documenten bestudeerd.

In lijn met het eerdere rapport van de adviescommissie Borghans constateren we een aantal problemen in het huidige COOL onderzoek:

- Er zijn problemen in het steekproefontwerp, met als gevolg het vrijwel mislukken van de oorspronkelijke opzet om leerlingen van 5 tot 18 te volgen, doordat leerlingen bij de overgang van PO naar VO over teveel scholen uitwaaieren. Ook binnen het $\mathrm{PO}$ en $\mathrm{VO}$ is, door de uitval van scholen en leerlingen, de longitudinale component maar gedeeltelijk geslaagd. Dat heeft deels te maken met het feit dat het accent ligt op het volgen van klassen in plaats van het volgen van leerlingen. Vanuit praktisch oogpunt is dat voorstelbaar, maar vanuit een longitudinale optiek is dat ongewenst.

- Het onderzoek vormt een te grote belasting voor de scholen met als gevolg een geringe responsbereidheid.

- Er is teveel getest zonder dat er een duidelijke onderzoeksvraag aan ten grondslag ligt. Dit komt deels door de opzet van $\mathrm{COOL}$ als 'dataverzamelingsproject'.

- Data en rapportages over COOL-VO zijn te laat opgeleverd.

- $\mathrm{Er}$ is onvoldoende toegankelijkheid van de data voor onderzoekers buiten het consortium en onvoldoende mogelijkheden voor onderzoekers buiten het consortium om hun eigen onderzoeksvragen in te brengen in het $\mathrm{COOL}$ onderzoek.

Op andere punten komen we tot een iets ander oordeel dan de adviescommissie Borghans:

- Als we kijken naar het aantal aanvullende opdrachten en beleidsrapporten, dan zijn de data van $\mathrm{COOL}$ veel vaker voor beleidsonderzoek gebruikt dan de vertegenwoordigers van OCW veronderstellen. 
- Ook de wetenschappelijke opbrengst is niet gering, althans afgemeten naar het aantal proefschriften (in totaal 18) dat (mede) gebaseerd is op COOL data. Men mag veronderstellen dat het aantal proefschriften dat deels op COOL is gebaseerd in de toekomst nog zal groeien, wanneer nieuwe registerdata aan de bestanden worden toegevoegd.

We constateren daarnaast een aantal problemen welke vooral samenhangen met de organisatie van het onderzoek:

- Er ontbreekt een duidelijke regie vanuit de PROO waardoor problemen weinig doortastend zijn aangepakt. Dat heeft onder andere te maken met de wisselende samenstelling in de PROO, waardoor er ook geen continuïteit is in de aansturing van COOL.

- Er ontbreekt een duidelijke overlegstructuur met beleidsmakers, waardoor er geen goed overzicht bestaat bij de stakeholders welke beleidsrapporten precies door COOL zijn opgeleverd en wat de mogelijkheden zijn voor aanvullend onderzoek.

- Er was binnen het consortium feitelijk sprake van twee consortia die elk hun eigen onderzoekdeel op een zo goed mogelijke wijze probeerden uit te voeren. Maar het ontbrak aan eenheid en een gezamenlijk gevoel van verantwoordelijkheid voor het geheel.

- In het algemeen verliep de communicatie gebrekkig. Het feit dat er meer beleidsrapporten of proefschriften zijn gemaakt dan belanghebbenden bij PROO of OCW denken, duidt erop dat de communicatie hierover niet goed verloopt.

- Er zijn in COOL aanmerkelijk meer data verzameld dan beschikbaar worden gesteld aan DANS. Het betreft hier voornamelijk extra data die in het VO zijn verzameld. Er zijn geen afspraken gemaakt met PROO om deze data publiek ter beschikking te stellen.

- In COOL worden - in tegenstelling tot de voorgangers PRIMA en VOCL - geen gegevens op school- en klasniveau meer verzameld. Dat vermindert de waarde van deze data voor vraagstukken van schooleffectiviteit aanzienlijk. Dat is gedaan om de belasting voor scholen te verminderen, maar daardoor dreigt $\mathrm{COOL}$ in een negatieve spiraal terecht te komen omdat de toegevoegde waarde van COOL ook afneemt.

Het is duidelijk dat de huidige opzet voor COOL niet echt toekomstbestendig is en dat er nagedacht moet worden over een nieuwe opzet. Wij denken dat een meer bestendige opzet gevonden kan worden in het slim combineren van registerdata (de basisregistratie), de stelselonderzoeken van de inspectie en aanvullende survey-onderzoeken (modules).

De basisregistratie wordt gevormd door de onderwijsloopbanen van de leerlingen, aangevuld met gegevens over de ontwikkeling in cognitieve prestaties (te ontlenen aan LVS en VVO), CITO eindtoets, basisschooladvies en gegevens van het Centraal Examen (CE). Deze worden in eerste instantie aangevuld met gegevens over de achtergrond van de leerlingen zoals bekend bij scholen (leerlinggewicht of bij voorkeur opleiding ouders) en enkele basisgegevens uit het GBA (ouders gehuwd/gescheiden, geboorteland kind, geboorteland ouders, samenstelling huishouden, plaats in de kinderrij) alsmede met de 
gegevens van DUO over de onderwijspositie van de andere kinderen uit het gezin. De koppeling van deze data zou kunnen plaatsvinden door DUO onder auspiciën van NRO. Deze gegevens kunnen verder worden verrijkt door het CBS door ze te koppelen aan andere registerdata voor de individuele leerlingen. Hierbij gaat het om zowel achtergrondgegevens van de ouders van de leerling, als om aanvullende gegevens over de leerlingen zelf. Uitkomsten van onderwijs worden in kaart gebracht door koppelingen te leggen met de schoolverlatersonderzoeken van het ROA en de registerdata (o.a. arbeidsmarktuitkomsten, gezinsvorming).

De onderwijsgegevens van de leerlingen kunnen gekoppeld worden op BRIN niveau aan kenmerken van scholen via de jaarlijkse stelselonderzoeken van de inspectie onder 400 scholen van het PO en 200 scholen van het VO. De respons op deze onderzoeken is vrijwel $100 \%$. Er wordt informatie verzameld wordt over bv. onderwijsmethoden, lestijden etc. Omdat deze stelselonderzoeken jaarlijks rouleren over de scholen, zal voor een groot aantal scholen deze informatie op enig moment beschikbaar zijn. Het is zinvol om te kijken of op deze scholen ook aanvullende informatie verzameld kan worden. De inspectie stelt zich op dit punt bereidwillig op, en het is belangrijk dat NRO hierover in gesprek gaat.

Aanvullend aan deze basisregistratie en stelselonderzoeken kunnen specifieke modules gepland worden, die bij een gerichte steekproef plaatsvinden en waarvan de omvang van de steekproef, frequentie en het design (cross-sectioneel, longitudinaal, doorlooptijd) afgestemd kan worden op de specifieke onderzoeksvraag. Dat heeft als voordeel dat - in vergelijking met het huidige $\mathrm{COOL}$ - de modules veel meer een gericht karakter hebben en niet noodgedwongen allemaal met dezelfde grote steekproef moeten meeliften. Mogelijke modules zijn: voorschoolse ontwikkeling, speciaal onderwijs, sociaal-emotionele ontwikkeling, burgerschap, keuze VO of de internationale onderzoeken waar Nederland in participeert.

Een dergelijke opzet is niet alleen van belang om het nationale onderwijsonderzoek goed te blijven uitvoeren, maar kan ook wetenschappelijke meerwaarde hebben. Bij cohortonderzoek is het verleidelijk om te kijken naar succesvolle voorbeelden in het buitenland, zoals het Duitse NEPS. Daar steekt het huidige COOL onderzoek wat mager bij af, en dat kan aanleiding zijn voor Nederlandse onderzoekers om juist van die buitenlandse cohortstudies gebruik te maken. Daarbij moeten we opmerken dat deze buitenlandse cohortstudies ook aanmerkelijk meer middelen ter beschikking hebben dan de Nederlandse cohortstudies. Zo heeft het NEPS een budget van 50 miljoen euro ter beschikking. Het is niet goed voorstelbaar dat een dergelijk budget ook in Nederland beschikbaar zal komen. Om ook in wetenschappelijk opzicht attractief te blijven voor onderzoekers, zal het Nederlandse cohortonderzoek zich op een andere manier moeten onderscheiden. Ons inziens is dat juist gelegen in het feit dat de combinatie van registerdata, testgegevens en aanvullende data uit surveys een uniek databestand kan opleveren dat niet alleen beleidsrelevant is, maar ook wetenschappelijk meerwaarde heeft. 
Het is belangrijk dat deze nieuwe opzet onder regie van NRO wordt uitgevoerd. Daarvoor is het zinvol om een klein instituut te maken, bestaande uit een nationale coördinator en een kleine staf die binnen NRO onder auspiciën van de OPRO valt. De coördinator is belast met de opzet en regie van al het onderzoek dat hierboven is weergegeven, zowel de basisregistratie als de aanvullende modules. Het nationale onderwijsonderzoek zou aangestuurd moeten worden door een beleidscommissie en een wetenschappelijke adviescommissie.

In het onderzoek spelen CBS, DUO, CITO en de inspectie een centrale rol. Het is van belang dat deze snel betrokken worden bij de verdere uitwerking en opzet van het onderzoek. Het is belangrijk dat NRO afspraken maakt met de betreffende instituten over de uit te voeren taken. De regie over deze taken blijft bij NRO, in casu de nationale coördinator. Van belang is ook dat CBS het als een kerntaak gaat zien om oudere databestanden te ontsluiten en te actualiseren. Dit moet onderdeel zijn van de opdracht aan CBS.

Het is heel belangrijk voor de kwaliteit en representativiteit van de data, dat de bereidheid van scholen om mee te werken vergroot wordt. Daarvoor is het belangrijk dat ook het veld zelf sterker betrokken wordt bij de opzet en vormgeving van verschillende modules. De NRO kan hierin een belangrijke rol spelen door in overleg tussen OCW, NRO en schoolbesturen een sterker draagvlak te creëren om met deze centrale onderzoeken mee te doen. Daarbij is het belangrijk om voor ogen te houden dat het onderzoek altijd een balans zal moeten zijn tussen datgene dat vanuit wetenschappelijke optiek van belang is, datgene dat vanuit beleidsoptiek van belang is en datgene dat voor de onderwijspraktijk van belang is. De OPRO is bij uitstek in staat om te bewaken dat deze drie invalshoeken voldoende in balans zijn. 


\section{Appendix 1}

\section{Lijst met gesprekken}

Kohnstamm Instituut (Guuske Ledoux, Jaap Roeleveld): Amsterdam, 10-12-2014

Cito (Anton Beguin, Jos Keuning): Arnhem, 12-12-2014

OCW (Ib Waterreus): Maastricht, 9-1-2015

OCW ( $1^{\mathrm{e}}$ gesprek met de onderzoekscoördinatoren: Geert de Boer (PO), Paul van Ooijen (VO), Jiska Riphagen (PO), Bernard Verlaan (BVE), lb Waterreus (Kennis); $2^{\mathrm{e}}$ gesprek met deskundigen van de skills groep van directie Kennis: Martine Blanken, André de Moor, Floor van Oort, Marc van der Steeg, lb Waterreus): Den Haag, 12-1-2015

ITS (Annemarie van Langen, Lia Mulder, Maarten Wolbers): Maastricht, 21-1-2015

CBS (Ivo Gorissen: CVB, Marijke Hartgers: Onderwijs): Den Haag, 22-1-2015; (Maarten Alders, directeur kwartaire sector) telefonisch op 28 en 30 mei 2015

Inspectie (Inge de Wolf), Maastricht, 29-1-2015

OECD (Flip de Fruyt, Oliver John, Koji Miyamoto): Den Haag, 2-2-2015

Universiteit Utrecht (Paul Leseman): Utrecht, 3-2-2015

GION (Roel Bosker, Anneke Timmermans): Utrecht, 13-2-2015

PROO (ex-PROO lid Lex Borghans): Maastricht, 13-3-2015

DUO (Erik Fleur): Den Haag 24-4-2015 



\section{Appendix 2}

Respons dataverzameling

COOL-PO

\begin{tabular}{|c|c|c|c|c|c|c|}
\hline Meting & $\begin{array}{l}\text { Aantal scholen } \\
\text { benaderd }\end{array}$ & Respons (\%) & $\begin{array}{l}\text { Aantal } \\
\text { scholen }\end{array}$ & $\begin{array}{l}\text { Aantal leerlingen } \\
\text { in: }\end{array}$ & $\begin{array}{l}\text { Aantal } \\
\text { leerlingen uit } \\
\text { vorige meting }\end{array}$ & $\begin{array}{l}\text { Aantal } \\
\text { leerlingen uit } \\
1 \text { na laatste } \\
\text { meting }\end{array}$ \\
\hline Meting 2007/08 & $\begin{array}{l}\text { ex-Prima6: } 623 \\
\text { vervangend: } 2.200\end{array}$ & $\begin{array}{l}\text { ex-Prima6: } 57 \% \\
\text { vervangend: } 8,5\end{array}$ & 550 & $\begin{array}{l}\text { groep 2: } 13.842 \\
\text { groep 5: } 12.609\end{array}$ & & \\
\hline Meting 2010/11 & $\begin{array}{l}\text { ex-CO0L1: } 550 \\
\text { vervangend: } 6.100\end{array}$ & $\begin{array}{l}\text { ex-COOL1: } 60 \% \\
\text { vervangend: } \\
3,7 \%\end{array}$ & 550 & $\begin{array}{l}\text { groep 2: } 11.995 \\
\text { groep 5: } 13.266\end{array}$ & $\begin{array}{l}\text { groep 5: } 5.876 \\
\text { groep 8: } 6.520\end{array}$ & \\
\hline Meting $2013 / 14$ & $\begin{array}{l}\text { ex-COOL2: } 550 \\
\text { vervangend: } 5.800\end{array}$ & $\begin{array}{l}\text { ex-COOL2: } 53 \% \\
\text { vervangend: } \\
2,5 \%\end{array}$ & 437 & $\begin{array}{l}\text { groep 2: } 8.995 \\
\text { groep 5: } 9.475\end{array}$ & $\begin{array}{l}\text { groep 5: } 4.815 \\
\text { groep 8: } 6.008\end{array}$ & groep 8: 2.820 \\
\hline
\end{tabular}




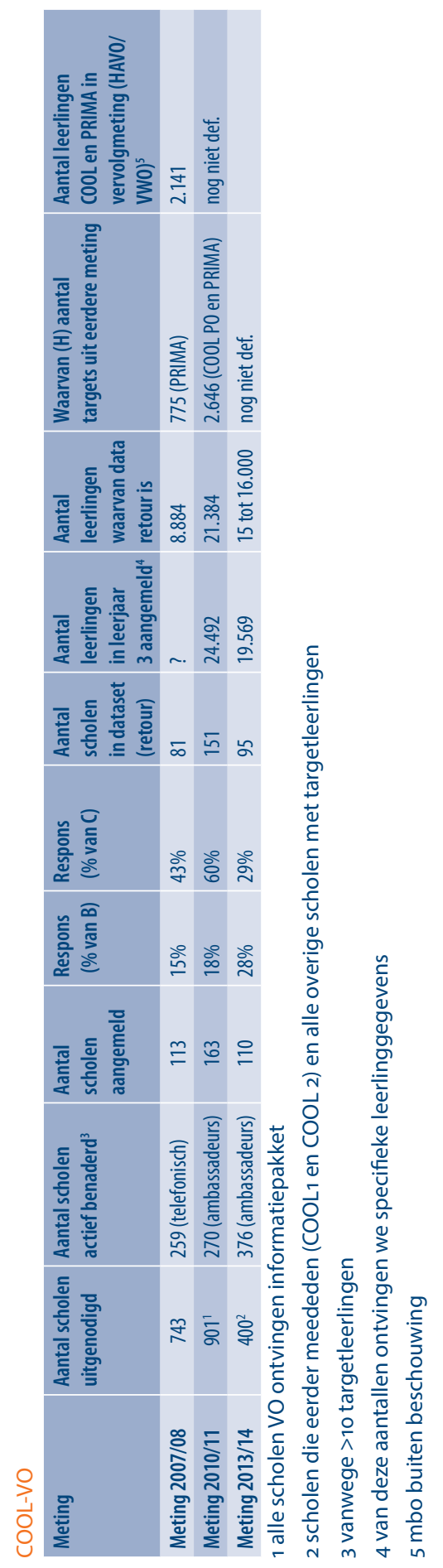

42 HOOFDSTUK 2 


\section{Appendix 3}

Overzicht COOL-publicaties (o.b.v. opgave aan PROO)

2014

PO:

- Bruggers, I., Driessen, G., \& Gesthuizen, M. (2014). Voor- en vroegschoolse voorzieningen, effectief of niet? Effecten van voor- en vroegschoolse voorzieningen op de taal- en rekenprestaties van leerlingen op de korte en langere termijn. Mens \& Maatschappij, 89(2), 117-150.

- Driessen, G. (2014). Cognitive and non-cognitive outcomes of Muslim schools. Paper Annual Meeting ECER 2014, Porto, Portugal, September 1-5, 2014.

- Driessen, G., \& Merry, M. (2014). Trends in educational disadvantage in Dutch primary school. Educational Review, 66(3), 276-292.

- Driessen, G., Leest, B., Mulder, L., \& Verrijt, T. (2014). Zittenblijven in Nederland: Een probleem? Tijdschrift voor Orthopedagogiek, 53(7/8), 297-311.

- Driessen, G., Leest, B., Mulder, L., Paas, T., \& Verrijt, T. (2014). Zittenblijven in het Nederlandse basisonderwijs: Een probleem? Nijmegen: ITS.

- Fettelaar, D., Mulder, L., \& Driessen, G. (2014). Ouderlijk opleidingsniveau en onderwijsachterstanden van kinderen. Veranderingen in de periode 1995-2011. Nijmegen: ITS.

- Merry, M., \& Driessen, G. (2014). On the right track? Islamic schools in the Netherlands after an era of turmoil. Race Ethnicity and Education, DOI 10.1080/13613324.2014.985586

- Mulder, L., Fettelaar, D., Schouwenaars, I., Ledoux, G., Dikkers, L. \& E. Kuiper (2014). De achterstand van autochtone doelgroepleerlingen. Nijmegen: ITS.

- Roeleveld, J., Karssen, M. \& Ledoux, G. (2014) Samenstelling van de klas en cognitieve en sociaal-emotionele uitkomsten. Amsterdam: Kohnstamm Instituut

- Bos, H., Gartrell, N., Roeleveld, J. \& Ledoux, G. (2014 published online by Youth \& Society) Civic Competence of Dutch Children in Female Same-Sex Parent Families: A Comparison With Children of Opposite-Sex Parents. Youth \& Society XX(X), 1-21

- Roeleveld, J., Driessen, G., Veen, I. van der, \& Ledoux, G. (in press). Ontwikkeling van onderwijsachterstanden in het basisonderwijs. In $\mathrm{H}$. van de Werfhorst en $\mathrm{H}$. Ganzeboom (Eds.), Een kloof van alle tijden. Verschillen tussen lager en hoger opgeleiden in werk, cultuur en politiek. Amsterdam: Amsterdam University Press.

- Karssen, A.M., Veen, I. van der, Volman, M. (2014). Kinderen van gemengde herkomst. Didaktief, 44, 31. 
VO:

- Marsh, H. W., Kuyper, H., Morin, A. J. S., Parker, P. D. Seaton, M. (2014). Big-fish-littlepond social comparison and local dominance effects: Integrating new statistical models, methodology, design, theory and substantive implications. Learning and Instruction, 33, 50- 66.

- Marsh. H.W., Kuyper, H., Seaton, M., Parker, P. D., Morin, A. J. S., Möller, J., \& Abduljabbar, A. S. (2014). Dimensional comparison theory: an extension of the internal/external frame of reference effect on academic self-concept formation. Contemporary Educational Psychology, 39, $326-342$.

- Keuning, J., \& Hemker, B. (2014). Estimation of Error Components in Cohort Studies: A Cross-Cohort Analysis of Dutch Mathematics Achievement. Educational Research and Evaluation, 20, 199-209, http://dx.doi.org/10.1080/13803611.2014.893832.

- Bennink, M., Croon, M.A., Keuning, J., \& Vermunt, J.K. (2014). Measuring student ability, classifying schools, and detecting item-bias at school-level based on studentlevel dichotomous attainment items. Journal of Educational and Behavioral Statistics, 39, 180-201, http://dx.doi.org/10.3102/1076998614529158.

- Korpershoek, H., Kuyper, H., \& van der Werf, M. P. C. (2014). Differences in students' school motivation: A latent class modelling approach. Social Psychology of Education. Doi: 10.1007/s11218-014-9274-6

- Korpershoek, H., Xu, J. K., Mok, M. M. C., Mclnerney, M. D., \& Van der Werf, M. P. C. (2015). Testing the multidimensionality of the Inventory of School Motivation in a Dutch student sample. Journal of Applied Measurement, 16(1), 41-59.

- Korpershoek, H. (2014). What motivates pre-university students to excel in school? In: M. V. C. Wolfensberger, L. Drayer, J. J. M. Volker (Eds.), Pursuit of excellence in a networked society; Theoretical and practical approaches, pp. 151-156. Münster, Germany: Waxmann Verlag GmbH.

PO:

- Driessen, G., \& Langen, A. van der (2013). Gender differences in primary and secondary education: Are girls really outperforming boys? International Review of Education. 59(1),67-86.

- Driessen, G., Veen, A., \& Veen, I. van der (2013). Het bereik van allochtone kinderen met voor- en vroegschoolse voorzieningen. Tijdschrift voor Orthopedagogiek, 52(7/8). 336-350.

- Driessen, G. (2013). De ontwikkeling van de onderwijspositie van de doelgroepen van het onderwijsachterstandenbeleid tussen 1995 en 2011. Tijdschrift voor Orthopedagogiek,52(2), 67-81.

- Driessen, G. (2013). Presteren meisjes eigenlijk wel beter in het onderwijs dan jongens? In C. Gravesteijn \& R. Diekstra (red.), Jongens \& meisjes. Zoek de verschillen?! (pp. 100-103). Assen: Van Gorcum. 
- Driessen, G. (2013). De bestrijding van onderwijsachterstanden Een review van opbrengsten en effectieve aanpakken. Nijmegen: ITS.

- Driessen, G., Leest, B. van., Mulder, L., Paas. \& Verrijt, T. (i.v., 2013). Blijven zitten? Zittenblijven in het basisonderwijs: leerlingen,. Scholen, argumenten, alternatieven. Nijmegen: ITS.

- Fettelaar, D. \& Smeets, E. (2013). Mogelijke indicatoren van schoolgewichten. Onderzoek naar de voorspellende waarde. Nijmegen: ITS

- Mulder, L. \& Paas, T. (2013). Monitor actieplan Basis voor Presteren en Bestuursakkoord Primair Onderwijs. $2^{e}$ meting. Nijmegen: ITS.

- Paas, T., Mulder, L. \& Roeleveld, J. (2013). Zittenblijvers en verwezen leerlingen in het cohortonderzoek COOL5-18. Nijmegen: ITS

- Veen, A., Karssen, M., Daalen, M. van, Roeleveld, J., Triesscheijn, B. \& Elshof, D. (2013) De aansluiting tussen voor-en vroegschoolse educatie en tussen vroegschoolse educatie en groep 3. Amsterdam: Kohnstamm Instituut

- Karssen, M., Veen, I. van der, Veen, A., Daalen, M. van \& Roeleveld, J. (2013) Effecten van deelname aan en kwaliteit van voor- en vroegschoolse educatie op de ontwikkeling van kinderen. Amsterdam: Kohnstamm Instituut

- Roeleveld, J., Smeets, E., Ledoux, G., Wester, M. \& Koopman, P. (2013) Prestaties en loopbanen van zorgleerlingen. Secundaire analyses op COOL-data ten behoeve van evaluatie Passend Onderwijs. Amsterdam/Nijmegen: Kohnstamm Instituut/ITS

- Smeets, E. \& Roeleveld, J. (2013) De leraar maakt het verschil. Didaktief, 43, 8, pp. 48-49

- Timmermans, A. C., Kuyper, H., Van der Werf, M. P. C. (2013). Schooladviezen en onderwijsloopbanen: Voorkomen, risicofactoren en gevolgen van onder- en over advisering. Groningen: GION.

\section{VO/MBO:}

Korpershoek heeft 3 artikelen ingediend:

- Gender differences in school motivation among eight ethnic groups from across the world.-

- Testing the multidimensionality of the Inventory of School Motivation in a Dutch student sample.

- Differences in students' school motivation: A latent class modelling approach.

Kuyper heeft 1 artikel ingediend:

- Better-than-average by proxy: Do parents overestimate their children's talents?

Keuning heeft 2 artikelen ingediend:

- Estimation of error components in cohort studies: A cross-cohort analysis of Dutch mathematics achievement

- Measuring student ability, classifying schools, and detecting item-bias at schoollevel based on student-level dichotomous items

2012

- Driessen, G. (in press). De ontwikkeling van de onderwijspositie van de doelgroepen van het onderwijsachterstandenbeleid tussen 1995 en 2011. Tijdschrift voor Orthopedagogiek. 
- Driessen, G. (2012). Trends in educational disadvantage in Dutch elementary school. Paper PROO Symposium Annual Meeting AERA 2012, Vancouver, BC, Canada, April 14-17, 2012.

- Driessen, G. (2012). Ontwikkelingen in het gebruik van Fries, streektalen en dialecten in de periode 1995-2011. Nijmegen: ITS.

- Driessen, G. (2012). De ambities waargemaakt? De ontwikkeling van de onderwijspositie van de doelgroepen van het onderwijsachterstandenbeleid tussen 1995 en 2011. In G. Driessen (red.), De doelgroepen van het onderwijsachterstandenbeleid: Ontwikkelingen in prestaties en het advies voortgezet onderwijs (pp. 3-35). Nijmegen: ITS.

- Driessen, G., \& Cuppen, J. (2012). leder het juiste advies voortgezet onderwijs? Tijdschrift voor Orthopedagogiek, 51(2) 55-69.

- Driessen, G., \& Cuppen, J. (2012). Het advies voortgezet onderwijs: Over- of onderadvisering van de doelgroepen van het onderwijsachterstandenbeleid? In G. Driessen (red.), De doelgroepen van het onderwijsachterstandenbeleid: Ontwikkelingen in prestaties en het advies voortgezet onderwijs (pp. 37-72). Nijmegen: ITS.

- Driessen, G., Mulder, L., \& Roeleveld, J. (2012). Cohortonderzoek COOL ${ }^{5-18}$. Technisch rapport basisonderwijs, tweede meting 2010/11. Nijmegen: ITS/ Amsterdam: Kohnstamm Instituut.

- Driessen, G., Veen, A., \& Veen, I. van der (in press). Het bereik van allochtone kinderen met voor- en vroegschoolse voorzieningen. Tijdschrift voor Orthopedagogiek.

- Ledoux, G. (2012). Zorgleerlingen in het basisonderwijs. Verschillen naar sociale herkomst en naar schoolpopulatie. Presentatie ORD 2012

- Ledoux, G. \& Roeleveld, J. (2011). Zal de invoering van referentieniveaus het niveau van het onderwijs verhogen? Toegepaste Taalwetenschap in Artikelen, 86-2, pp.17-24

- Ledoux, G. \& Roeleveld, J. (2012). De sociaal-emotionele ontwikkeling van zorgleerlingen in verschillende zorgsettingen. Presentatie ORD 2012

- Mooij, T., Roeleveld, J., Fettelaar, D. \& Ledoux, G. (2012). Kwaliteitsbeoordeling van scholen primair onderwijs: Het correctiemodel van de inspectie vergeleken met alternatieve modellen. Pedagogische Studiën, 89, pp. 272-287

- Mulder, L (2012). Allochtone leerlingen en onderwijsachterstand. De ontwikkeling van specifiek naar generiek beleid. In: Jaarboek Minderheden. Den Haag: SCP

- Paas, T., L. Mulder \& J. Roeleveld (2012). Zittenblijvers en verwezen leerlingen in het cohortonderzoek COOL5-18. Nijmegen: ITS.

- Roeleveld, J. (2012). Inleiding Symposium Resultaten van de tweede ronde van het cohortonderzoek COOL5-18 in het basisonderwijs. Presentatie ORD 2012

- Roeleveld, J., Driessen, G., Veen, I. van der, \& Ledoux, G. (in press). Ontwikkeling van onderwijsachterstanden in het basisonderwijs. In $\mathrm{H}$. van de Werfhorst en $\mathrm{H}$. Ganzeboom (Eds.), Onderwijs en stratificatie: Ongelijkheid, arbeidsmarkt en participatie in de afgelopen decennia. Amsterdam: Amsterdam University Press.

- Veen, A., Veen, I. van der, \& Driessen, G. (2012). Het bereik van allochtone kinderen met Voor- en Vroegschoolse Educatie. Amsterdam: Kohnstamm Instituut. 


\section{Rapporten VO}

- Béguin, A., Keuning, J., \& Van der Werf, M.P.C. (2009). Monitor doorlopende leerlijnen: Resultaten van de nul-meting. Groningen: GION.

- Keuning, J., Hendriks, H., \& Zijsling, D. (2012). Cohortonderzoek COOL5-18: Technisch rapport meting VWO-6 in 2011. Groningen: GION.

- Keuning, J., Hendriks, H., \& Zijsling, D. (2012). Cohortonderzoek COOL5-18: Technisch rapport meting HAVO-5 in 2010. Groningen: GION.

- Spijkerboer, A., Maslowski, R., Keuning, J., Van der Werf, M.P.C. \& Béguin, A. (2012). Evaluatie van de nieuwe wetgeving voor de onderbouw voortgezet onderwijs. Groningen: GION.

- Keuning, J. \& Béguin, A. (2011). Effecten van de vernieuwde onderbouw op de prestaties van leerlingen in leerjaar 3 van het voortgezet onderwijs: Een vergelijking tussen COOL-1 en COOL-2. Arnhem: Cito.

- Spijkerboer, A., Maslowski, R., Keuning, J., Van der Werf, M.P.C. \& Béguin, A. (2012). Evaluatie van de nieuwe Tweede Fase in de onderbouw voortgezet onderwijs. Groningen: GION.

- Zijsling, D., Keuning, J., Naayer, H., \& Kuyper, H. (2012). Cohortonderzoek COOL5-18: Technisch rapport meting VO-3 in 2011. Groningen: GION.

- Zijsling, D., Keuning, J., Kuyper, H., Van Batenburg, T. \& Hemker, B. (2009). Cohortonderzoek COOL5-18: Technisch rapport. Eerste meting $\mathrm{COOL}_{5}-18$ in het derde leerjaar voortgezet onderwijs. Groningen: GION.

Artikelen VO

- Elst, W. van der, Ouwehand, C., Werf, G. van der, Kuyper, H., Lee, N., \& Jolles, J.

- (2012). The Amsterdam Executive Function Inventory (AEFI): psychometric properties and demographically-corrected normative data for adolescents aged between 15 and 18 years. Journal of Clinical and Experimental Neuropsychology, 34, 160-171. DOI: $10.1080 / 13803395.2011 .625353$.

- Keuning, J., \& Béguin, A. (2010). Achmed spelt (soms) beter. Didaktief, 6, 11-12.

- Ledoux, G. \& Naayer, H. (2010). Allochtone leerling denk na over burgerschap. Didaktief, 6, 5-7

- Kuyper, H. (2010). Hoe zit motivatie eigenlijk in elkaar? Didaktief, 6, 8-10

Publicaties door derden

- Rusconi, R.W. (2012) Value-added vs. snapshot measurements: the value added by primary schools in the Netherlands. Amsterdam: Universiteit van Amsterdam, afd. Pedagogiek en Onderwijskunde [masterscriptie onderwijskunde ]

- Driessen, G., \& Merry, M. (2011).The effects of the integration and generation of immigrants on language and numeracy achievement. Educational Studies, 37(5), 581-592.

- Driessen, G. (2011). Gender differences in education. Is there really a "boys' problem"? Paper Annual Meeting ECER, Berlin, D, September 12 - 16, 2011.

- Driessen, G. (2011). The teacher recommendation: A valid instrument for selecting ethnic minority students into secondary school tracks? Paper Annual Meeting ECER, Berlin, D, September $12-16,2011$. 
- Driessen, G., \& Langen, A. van (2011). Staan jongens in het primair en voortgezet onderwijs op achterstand? Pedagogische Studiën, 88(5), 323-338.

- Driessen, G., \& Langen, A. van (2011). Mogelijke verklaringen voor onderwijsachterstanden van jongens. Pedagogiek, 31(2), 155-171.

- Roeleveld, J., Driessen, G., Ledoux, G., Cuppen. J., \& Meijer, J. (2011). Doelgroepleerlingen in het basisonderwijs. Historische ontwikkeling en actuele situatie. Amsterdam: Kohnstamm Instituut.

- Driessen, G. (2011). Onderadvisering van allochtone leerlingen? Utrecht: Inspectie van het Onderwijs.

- Driessen, G. (2011). Die arme jongens. Worden ze in het onderwijs door de meisjes voorbijgestreefd? Raffia, 23(2), 3-5.

- Driessen, G. (2011). Geen onderadvisering allochtone leerlingen. Didaktief, 40(6), 31.

- Ledoux, G., Roeleveld, J., Driessen, G., Cuppen, J., \& Meijer, J. (2011). Prestaties en loopbanen van doelgroepleerlingen in het onderwijsachterstandenbeleid. Stand van zaken en ontwikkelingen in de periode 1994-2007. Nijmegen/Amsterdam: ITS/ SCO-Kohnstamm Instituut.

- Langen, A. van, \& Driessen, G. (2010). Jongens verschillen van meisjes in werkhouding en gedrag. ITS Nieuwsbrief, oktober 2010.

- Karssen, M., Veen, I. van der \& Roeleveld, J. (2011) Effecten van schoolsamenstelling op schoolprestaties in het Nederlandse basisonderwijs. Paper OnderwijsResearchDagen ORD 2011, Maastricht, 8-10 juni 2011.

- Roeleveld, J., Mooij, T., Fettelaar, D. \& G. Ledoux (2011) Correctiefactoren bij opbrengstmaten in het primair onderwijs. Amsterdam / Nijmegen: Kohnstamm Instituut / ITS

- Roeleveld, J., R., Driessen, G., Ledoux, G. (2011). Onderwijsachterstanden van oude en nieuwe gewichtenleerlingen. Paper BOPO-symposium OnderwijsResearchDagen ORD 2011, Maastricht, 8-10 juni 2011.

- Driessen, G. (2011). Over- en onderadvisering bij de overgang naar het voortgezet onderwijs. Paper BOPO-symposium OnderwijsResearchDagen ORD 2011, Maastricht, 8-10 juni 2011.

- Driessen, G. (2011). Ontwikkelingen in prestaties en onderwijspositie tussen 1994 en 2008. Paper BOPO-symposium OnderwijsResearchDagen 2011, ORD 2011, Maastricht, 8-10 juni 2011.

- Roeleveld, J. (2011) Verschillen in groei van vaardigheden gedurende het basisonderwijs. Paper BOPO-symposium OnderwijsResearchDagen 2011, ORD 2011, Maastricht, 8-10 juni 2011.

Publicaties door derden

- Cuppen, J. (2011). Schoolprestaties in het basisonderwijs en het advies voor het voortgezet onderwijs. Nijmegen: Radboud Universiteit Nijmegen, Vakgroep Sociologie. [Masterscriptie sociologie]

- Dronkers, J. (2011). De effecten van etnische diversiteit van Nederlandse scholen op onderwijsprestaties van 15-jarige scholieren in PISA 2009 en leerlingen van groep 8 in Nederlandse basisscholen van de COOL data 2007. Presentatie 28-09-11 CPB Den Haag. Maastricht: Universiteit Maastricht. 
- Herweijer, I., \& Brink, Y. van den (2011) Effecten van etnische diversiteit op leerprestaties in het basis- en voortgezet onderwijs? Paper OnderwijsResearchdagen Maastricht. Den Haag: SCP.

- Herweijer, L. (2011). Gemengd leren. Etnische diversiteit en leerprestaties. Den Haag: SCP.

- Inspectie van het Onderwijs (2011). De staat van het onderwijs. Onderwijsverslag 2009/2010. Utrecht: Inspectie van het Onderwijs.

- Kraaykamp, G., Driessen, G., \& Wolbers (2011). Emancipation of culture, curriculum and countries, and the male-female gap in educational success. Nijmegen: Radboud Universiteit Nijmegen, Vakgroep Sociologie. [Subsidie-aanvrage NWO/MaGW TOP]

2010

- Béguin, A., Keuning, J., \& Van der Werf, M.P.C. (2009). Monitor doorlopende leerlijnen: Resultaten van de nul-meting. Groningen: GION. Rapport in opdracht van het ministerie van OCW

- Dam, G.ten, Geijsel, F., Reumerman, R. \& Ledoux, G. (2010). Burgerschapscompetenties: de ontwikkeling van een meetinstrument. Pedagogische Studiën, 2010, (87), 313-333.

- Driessen, G. (2009). Prestaties, gedrag en houding van basisschoolleerlingen. stand van zaken in 2008 en ontwikkelingen sinds 2001. Nijmegen: ITS. Rapport in opdracht van het ministerie van OCW

- Driessen, G. (2010). Integratie, generatie en prestatie. Samenhangen tussen de mate van integratie van allochtone ouders en de herkomstgeneratie en taal-en rekenvaardigheid van hun kinderen. Paper OnderwijsResearchDagen ORD 2010, Enschede, 23-25 juni 2010.

- Driessen, G. (2010). Opleiding en taal cruciaal. Didaktief (Special COOL5-18), 1-3.

- Driessen, G. (2010). Structurele en culturele integratie, generaties en onderwijsprestaties. Migrantenstudies, 26(3), 262-279.

- Driessen, G., \& Langen, A. van (2010). De onderwijsachterstand van jongens. Omvang, oorzaken en interventies. Nijmegen: ITS.

- Keuning, J. \& Béguin, A. (2010). Achmed spelt (soms) beter. Didaktief (Special COOL518), 6, 11-12.

- Kuyper, H. (2010). Hoe zit motivatie eigenlijk in elkaar? Didaktief (Special COOL5-18), 6, 8-10.

- Ledoux, G., \& Naayer, H. (2010). Allochtone leerling denkt na over burgerschap. Didaktief (Special COOL5-18), 6, 5-7.

- Ledoux, G. \& Van der Veen, I. (2010). Burgerschapscompetentie van leerlingen aan het eind van het basisonderwijs. Paper voor de Onderwijsresearchdagen 2010, Enschede. Amsterdam: Kohnstamm Instituut.

- Paas, T. \& L. Mulder (2010). Dalton doet het beter dan doorsnee school. Didaktief (Special COOL5-18), 2, 3-4.

- Paas, T \& L. Mulder (2010). De prestaties en niet-cognitieve kenmerken van leerlingen op traditionele vernieuwingsscholen. Een verkennende studie. Paper OnderwijsResearchDagen ORD 2010, Enschede, 23-25 juni 2010. 
- Roeleveld, J. (2010) Schoolprestaties van oude en nieuwe gewichtenleerlingen. Paper voor de OnderwijsResearchDagen 2010, Enschede. Amsterdam: Kohnstamm Instituut.

- Smeets, E., Driessen, G., Elfering, S., \& Hovius, M. (2009). Allochtone leerlingen en speciale onderwijsvoorzieningen. Nijmegen: ITS.

- Werf, M. P. C. van der (2010). Wat is COOL ${ }^{5-18}$ ? Didaktief (Special COOL5-18), 6, 1

2009

- Driessen, G. (2009). Prestaties, gedrag en houding van basisschoolleerlingen. stand van zaken in 2008 en ontwikkelingen sinds 2001. Nijmegen: ITS

- Rapport in opdracht van het ministerie van OCW. Doelgroep: OCW, overige geïnteresseerden.

- Polman, H. \& L. Mulder (2009) Speciale doelgroepen in het basisonderwijs. Nijmegen: ITS. Rapport in opdracht van het KPC. Doelgroep: onderwijsveld, OCW, overige geïnteresseerden.

- Driessen, G. (2009) Integratie, generatie en onderwijsprestaties. Nijmegen: ITS. Artikel aangeboden aan Migrantenstudies

- Mulder, L., A. van der Hoeven-Van Doornum \& J. Roeleveld (2009). Aantallen en typen zorgleerlingen in schooljaar 2007/08. Resultaten van de aanvullende dataverzameling . $\mathrm{COOL}^{5-18}$ ten behoeve van het monitoren van zorgleerlingen. Nijmegen/ Amsterdam: ITS/Kohnstamm Instituut. Notitie in opdracht van ministerie van OCW . Doelgroep: OCW, onderwijsveld, overige geïnteresseerden.

- Ledoux, G., Reumerman, R., Geijsel, F. \& Ten Dam, G. (submitted). Burgerschapscompetenties van jongeren in Nederland. Amsterdam: SCO-Kohnstamm Instituut/ILO. Artikel aangeboden aan Pedagogische Studiën.

- In voorbereiding: Rapport voor de Onderwijsraad over deelname van kinderen aan voorschoolse voorzieningen, op basis van data uit COOL5-18 en Pre COOL. Amsterdam: SCO-Kohnstamm Instituut.

Publicaties door derden

- SCP: Sociaal en cultureel rapport 2008 (eerste data over burgerschapscompetenties)

- SCP: Jaarrapport Integratie 2009

\section{COOL Speciaal}

2012-2013

- Roeleveld, J., Smeets, E., Ledoux, G., Wester, M., \& Koopman, P. (2013). Prestaties en loopbanen van zorgleerlingen. Secundaire analyses op COOL-data ten behoeve van evaluatie Passend Onderwijs. Amsterdam/Nijmegen: Kohnstamm Instituut/ITS.

- Ledoux, G., Roeleveld, J., Van Langen, A., \& Paas, T. (2012). COOL Speciaal. Technisch rapport meting schooljaar 2010/2011. Amsterdam: Kohnstamm Instituut.

- Ledoux, G., Roeleveld, J., Van Langen, A., \& Smeets, E. (2012). COOL Speciaal. Inhoudelijk rapport. Amsterdam: Kohnstamm Instituut. 


\section{Pre-COOL}

2013-2015

- Akgunduz, Y.E., Jongen, E., Leseman, P., \& Plantenga, J. (2013). Cutting from the future? Impact of a subsidy reduction on child care quality in the Netherlands. Utrecht: Tjalling Koopmans Institute Universiteit Utrecht, Discussion Paper Series nr: 13-18.

- Broekhuizen, M.L., Van Aken, M.A.G. , Dubas, J.S., Van der Schoot, R., \& Leseman, P.P.M. (2013). Combined effects of parenting and child care quality on child internalizing and externalizing behavior. Utrecht: Universiteit Utrecht (revised manuscript resubmitted for publication).

- Broekhuizen, M.L., Slot, P.L., Dubas, J.S., \& Van Aken, M.A.G. (2014). Teachers' emotional and behavioral support and toddlers' self-control: Relations with social and emotional well-being during play. Utrecht: Universiteit Utrecht (manuscript submitted for publication).

- Broekhuizen, M.L., Van Aken, M.A.G. , Dubas, J.S., Mulder, H., \& Leseman, P.P.M. (2014). Individual differences in effects of child care quality: The role of child affective selfregulation and gender. Utrecht: Universiteit Utrecht (manuscript submitted for publication).

- Broekhuizen, M.L., Van Aken, M.A.G., Dubas, J.S., \& Leseman, P.P.M. (2014). Effects of early center-based child care quality on children's socio-emotional outcomes: Does quantity of care matter? Utrecht: Universiteit Utrecht (revised manuscript resubmitted for publication).

- Broekhuizen, M.L., Van Aken, M.A.G., Dubas, J.S., \& Leseman, P.P.M. (2014). Kwaliteit van kinderopvang en de sociale en emotionele ontwikkeling. Wat doen temperament en het aantal dagen ertoe? Beleid, Bestuur, Management en Pedagogiek in de Kinderopvang, 2014, 5, 33-37.

- Broekhuizen, M. (2015). Differential effects of early child care quality on children's socio-emotional development. Utrecht: Universiteit Utrecht, academisch proefschrift.

- Mulder, H., Hoofs, H., Verhagen, J., van der Veen, I., \& Leseman, P.P.M. (2014). Psychometric properties and convergent and predictive validity of an executive function test battery for two-year-olds. Frontiers in Psychology, 5:733.

- Leseman, P.P.M., \& Slot, P.L. (2013). Kwaliteit en curriculum van voorschoolse opvang en educatie in Nederland: relaties met structurele kenmerken, organisatiekenmerken en gebruik educatieve programma's (Rapport BOPO). Utrecht: Afdeling Orthopedagogiek, Universiteit Utrecht.

- Slot, P.L., Leseman, P.P.M., Verhagen, J., \& Mulder, H. (2013). Associations between structural quality and process quality in Dutch early childhood education and care. Utrecht: Universiteit Utrecht (revised manuscript resubmitted for publication)

- Slot, P.L., Leseman, P.P.M., Mulder, H., \& Verhagen, J. (2013). Quality and curriculum of early childhood center-based care predicting growth of two-year-olds' vocabulary and attention skills over one year. Utrecht: Universiteit Utrecht. (revised manuscript resubmitted for publication) 
- Slot, P.L., Boom, J., Verhagen, J., \& Leseman, P.P.M. (2014). Psychometric quality of the Classroom Assessment Scoring System Toddler. Utrecht: Universiteit Utrecht (manuscript submitted for publication)

- Slot, P.L., Mulder, H., \& Leseman, P.P.M. (2014). Preschoolers' cognitive and emotional self-regulation in pretend play: Relations with executive functions, quality of play, and classroom quality. Utrecht: Universiteit Utrecht (manuscript submitted for publication)

- Slot, P.L. (2014). Early childhood education and care in the Netherlands: Quality, curriculum and relations with child development. Utrecht: Universiteit Utrecht, academisch proefschrift.

- Slot, P.L. (2014). Kwaliteit doet er toe: Aanwijzingen voor effecten op woordenschat en aandachtsontwikkeling. Beleid, Bestuur, Management en Pedagogiek in de Kinderopvang, 2014, 3, 33-37

- Verhagen, J., De Bree, E., Mulder, H., \& Leseman, P. (2014). Effects of vocabulary and phonotactic probability on two-year-olds' nonword repetition. Utrecht: Universiteit Utrecht (revised manuscript resubmitted for publication).

\section{Overzicht lopende of verschenen proefschriftstudies die (deels) gebruik maken van}

$\mathrm{COOL}$ data (voor zover bekend):

Lisette Hornstra (onderwijskunde UvA)

Merlijn Karssen (onderwijskunde UvA)

Ralph Rusconi (onderwijskunde UvA)

Bram Eidhof (onderwijskunde UvA)

Ellen Geboers (onderwijskunde UvA)

Gert-Jan Veerman (sociologie UvA)

Jacqueline Witschge (sociologie UvA)

Frank Wanders (sociologie UvA)

Nienke Ruysch (economie UvA)

Reyn van Ewijk (economie UvA)

Roxanne Korthals (economie Universiteit Maastricht)

Roel van Elk (economie Erasmus Universiteit)

Peter Scheltinga (onderwijskunde RuG)

Harm Naayer (onderwijskunde RuG)

M. Broekhuizen (ontwikkelingspsychologie, UU)

Pauline Slot (pedagogiek, UU)

Y.E Akgunduz (economische wetenschappen, UU)

S.D.M. Schaik (pedagogiek, UU) 


\section{Appendix 4}

Mailverkeer met DANS om data beschikbaar te krijgen

Date: 14 Jan 2015 12:02:33 CET

From: info@dans.knaw.nl

To: hvandermaas@gmail.com

Subject: DANS EASY: response to permission request for pre-COOL 2-jarigen cohort eerste meting 2010-2011

Dear H.L.J. van der Maas,

The depositor (A.M.H. Heurter) of the dataset "pre-COOL 2-jarigen cohort eerste meting 2010-2011" has responded to your permission request.

Your permission request has been returned. The depositor of the dataset would like to receive more information. Please read the explanation by the depositor. Then review your permission request here:

Explanation by depositor:

Geachte heer van der Maas,

Graag ontvangen wij iets meer informatie over het onderzoeksplan om na te kunnen gaan of de onderzoeksvraag niet interfereert met de onderzoekvragen van het pre-COOL consortium.

Met vriendelijke groet,

Anna Heurter 



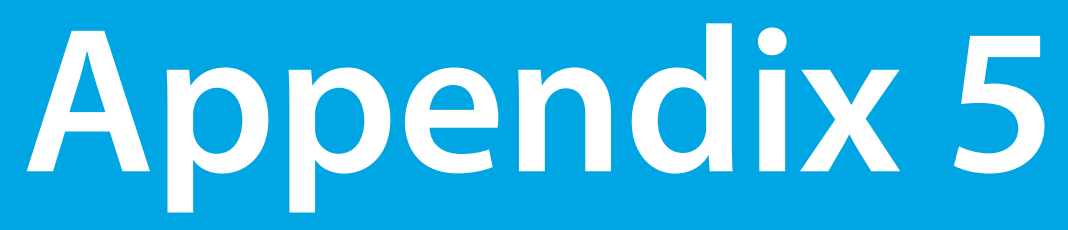

\section{Beleid CBS inzake toegang microdata}

De Directeur-Generaal van de Statistiek (DG) kan toegang tot microdata verlenen aan een aantal categorieën in de CBS-wet genoemde instellingen, waaronder Nederlandse Universiteiten en Planbureaus. Voor andere instellingen kan hij die toegang slechts verlenen na daartoe gemachtigd te zijn door de Centrale Commissie voor de Statistiek (CCS). De CCS onderscheidt daarbij verschillende typen onderzoeksinstellingen. In alle gevallen staan de eisen centraal dat de te machtigen organisaties een primaire onderzoeksdoelstelling hebben en publiceren voor de openbaarheid. Externe onderzoekers krijgen alleen rechten op de bestanden en de gegevens die nodig zijn voor hun onderzoek. Daarvoor dient een projectplan ingediend te worden.

Daarnaast is het onder voorwaarden mogelijk om bestanden van externen te versleutelen en op persoonsniveau koppelbaar te maken aan de bestanden van het CBS. Hier moeten dan wel voldoende persoonsgegevens in aanwezig zijn (BSN, of geboortedatum, geslacht, postcode en peildatum voor de postcode). Dit geldt ook voor eigen bestanden met informatie over bedrijven; waarbij die bedrijven zijn geïdentificeerd op bijv. KvK nummer. Er is een speciale uploadprocedure om dergelijke bestanden aan te leveren.

Er zijn twee manieren om de microdata uit de catalogus te benaderen: On Site en Remote Access. In het kort houdt On Site in dat je als (gemachtigde) onderzoeker naar het CBS-gebouw komt en daar op de bestanden werkt. De andere optie is via Remote Access, waarbij je op een computer bij je eigen instelling via een beveiligde verbinding werkt op de server van het CBS. Je krijgt dan een eigen onderzoeksaccount waar je je analyses kan uitvoeren en je resultaten en analysebestanden kunt bewaren. Onderzoekers mogen alleen statistische resultaten van hun onderzoeksaccount exporteren; er mogen geen gegevens van individuele personen of instellingen het CBS (d.w.z. de On Site of Remote Access omgeving) verlaten. Daarom wordt de output van de analyses pas na controle op onthulling (van individuele gegevens van personen of bedrijven; standaardregel is dat iedere cel minimaal 10 waarnemingen bevat) door het CBS naar het e-mail adres van de onderzoeker opgestuurd. Daarnaast moeten onderzoekers die met microdata willen werken ook een geheimhoudingsverklaring tekenen. Zij blijven dus zelf verantwoorde- 
lijk voor het niet onthullen van gegevens over individuele personen, bedrijven of instellingen. Er wordt niet gecontroleerd op de kwaliteit van de analyses. 